\title{
A NEW ANTITRUST PROBLEM: VERTICAL INTEGRATION IN CORRESPONDENT BANKING*
}

\author{
Arthur D. Austin† \\ ElinOR HARRIS SOLOMON††
}

\section{INTRODUCTION}

Although the banking community was certainly already aware of the omnipresence of the antitrust laws, in United States $v$. First National Bancorporation, Inc., ${ }^{1}$ it received further evidence of their ubiquity when the Government's attack on a market extension merger was supplemented with the allegation that the acquisition by a bank supplying correspondent services of one of its customer banks violated section 7 of the Clayton Act. ${ }^{2}$ In a challenge of first impression, the Justice Department charged that a large Colorado correspondent bank was acquiring captive outlets for its correspondent services, thereby foreclosing rival correspondent banks.

Although the district court held against the Justice Department on both counts, and the Supreme Court did not deal with the correspondent banking issue, ${ }^{3}$ the implications of the Government's challenge are of first priority. What is involved is a pervasive and longstanding banking practice of substantial policy and functional weight. Its functional significance is derived from the critical role correspondent banking plays in strengthening the entire banking system; ${ }^{4}$ its policy relevance is due to the substantial contribution the practice makes to preserving the integrity of small independent banks. ${ }^{5}$ The importance of the

* The views expressed in this Article are those of the authors and do not necessarily accord with those of any federal agency.

† Professor, Franklin T. Backus Law School, Case Western Reserve University. B.S 1958, University Of Virginia; L.L.B. 1963, Tulane University. Member, Virginia and District of Columbia Bars.

i† Senior Financial Economist, Evaluation Section, Antitrust Division, Department of Justice. A.B. 1944, Mount Holyoke College; A.M. 1945, Ph.D. 1948, Radcliffe College and Harvard University.

1329 F. Supp. 1003 (D. Colo. 1971), aff'd per curiam by an equally divided Court, 410 U.S. 577 (1973) (Powell, J., not participating).

215 U.S.C. $\$ 18$ (1970).

${ }^{3}$ United States v. First Nat'l Bancorporation, Inc., 410 U.S. 577 (1973). For a discussion of the market extension implications of the case, see Hansen, Greeley Bank; Some Speculations, 90 BANKING L.J. 578 (1973).

${ }^{4}$ Notes 10-20 infra \& accompanying text.

5 Notes 212-16 infra \& accompanying text. 
practice has been further elevated by technological advances, new forms of correspondent services, and heightened demand for deposits. Moreover, the industry must now face up to the possibility of further scrutiny, for the glare of antitrust law, once affixed by either government or private party, tends to remain on target. ${ }^{6}$

A major problem for bankers is that at the present time they must evaluate the application of the antitrust laws to vertical integration in a vacuum of experience. Neither the First National Bancorporation decision ${ }^{7}$ nor several earlier cases touching on correspondent banking settled by nolo contendere ${ }^{8}$ explore fully the analytical stresses produced by the unique characteristics inherent in the practice. Paying heed to these unique characteristics within the context of the needs of the industry and the relevant policy pressures, this Article endeavors to identify the significant problem areas and to chart out general guides for applying antitrust to vertical integration in correspondent banking. Prefacing the antitrust analysis is a description of the practice followed by a survey of the factors that determine the location, degree, and significance of market power in the relationship between city correspondent and country banks.

\section{CoRrespondent Banking}

\section{A. General Description}

Correspondent banking is an interbank practice whereby "city" correspondent banks provide a cluster of services to

${ }^{6}$ The Justice Department has brought 3 other suits involving correspondent banking as peripheral issues: United States v. First National Bancorporation, Inc., Civil No. C-3077 (D. Colo., filed Apr. 28, 1971), alleges:

[T] his acquisition combined with the trend of acquisitions by leading banking organizations in Colorado of independent banks with substantial positions in markets throughout many parts of the state will substantially reduce existing competition in providing correspondence banking services in Colorado, increase barriers to new entry into correspondent banking services in Colorado, and effectively foreclose the remaining independent banks in many markets from access to correspondent banking services in Colorado, and the possibility of deconcentration in commercial banking in the Colorado Springs SMSA will be substantially reduced.

United States v. Marine Bancorporation, Inc., Civil No. 237-71C2 (W.D. Wash. Jan. 31, 1973), appeal docketed, No. 73-38 (U.S. June 30, 1973), alleges that a merger between 2 banks offering correspondent services will result in the elimination of actual and potential competition. The Government is appealing Marine Bancorporation to the Supreme Court. United States v. Wells Fargo.Bank, Nat'l Ass'n, Civil No. CT-2-98-RHS (D.S.F. Cal., filed Jan. 17, 1972, dismissed Nov. 21, 1972), alleges that a -merger between banks offering correspondent services will eliminate competition in serving smaller California banks and contribute to further concentration in correspondent banking. The Wells Fargo merger was withdrawn by defendants.

7 The district court held against the Government without discussion of the effects of the elimination of horizontal competition among correspondent banks.

${ }^{8}$ In 1963 a Minnesota clearing house association was indicted for fixing prices of 
smaller "country" banks in exchange for interbank deposits. Dating back to colonial times, ${ }^{9}$ correspondent banking originally provided an extended network of independent unit banks with a link to financial centers, and at the same time furnished substitute central banking functions. ${ }^{10}$ Today, as a vital component of the era of electronic banking, it enables city correspondents to provide customers with a range of services that is varied, extensive and constantly expanding; one survey lists as many as fifty different categories. ${ }^{11}$ Although usually tailored to satisfy individual customer needs, the typical city-country bank relationship embraces a fairly standard "package" of services. What follows is a brief description of those services that are most frequently included in the package.

Correspondent banking supplements Federal Reserve and private clearing house operations by furnishing check clearing and collection services. ${ }^{12}$ Virtually all country banks find advantages in clearing a large part of non-local checks through correspondent facilities, with small banks especially dependent on correspondents for check processing. ${ }^{13}$ Another standard component of the service package is loan participation. In areas characterized by active growth the demand for loans often surpasses the deposits generated, or specific loan requests are for amounts in excess of a local bank's legal lending limit. ${ }^{14}$ In such situations, correspondent banks often assist by making the necessary funds available through overline loans or, in some cases, they purchase loans outright from the country bank. ${ }^{15}$

services. In a companion case the leading banks of Minneapolis were indicted for fixing prices of correspondent services. In addition to a fine of $\$ 125,000$, the defendants were enjoined from repetition of similar conduct. United States v. Northwestern Nat'l Bank, 1964 Trade Cas. ๆ 71,020 (D. Minn. 1964).

9 One source sets the date of the earliest correspondent banking relationship (involving New York and Philadelphia banks) at 1784. McClain, Correspondent Bank Relationships, in W. Baughn \& C. Walker, The Bankers' Handbook 961 (1966).

10 K. Finney, Interbank Deposits: The Purpose and Effect of Domestic Balances, 1934-54, at 1-2 (1958); E. Reed, Commercial Bank Management 28 (1963).

${ }^{11}$ Speaking Frankly on Correspondent Banking, Banking, Oct. 1953, at 36-37; see $\mathrm{K}$. FINNEY, supra note 10 , at $2-20$.

${ }_{12}$ This is the most common service. Knight, Correspondent Banking, Balances and Services, Fed. Reserve Bank of Kansas City Monthly Rev., Nov. 1970, at 10 [hereinafter cited as Knight, pt. I].

${ }_{13}$ House Comm. on Banking and Currency, Subcomm. on Domestic Finance, 88th Cong., 2d Sess., A Report on the Correspondent Banking System 2 (Comm. Print Oct. 21, 1964) [hereinafter cited as REPORT ON THE CoRrespondent Banking SYSTEM].

${ }^{14}$ Knight, Correspondent Banking, Loan Participation and Fund Flows, FeD. RESERve Bank of Kansas Ciry MonThly REv., Dec. 1970, at 12 [hereinafter cited as Knight, pt. II]; REPORT ON THE CORRESPONDENT BANKING SYSTEM, supra note 13, at 2-4; Stivers, $A n$ Analysis of the Techniques Utilized to Meet the Loan Participation Needs of a Correspondent Bank, J. Commercial Bank Lending, Dec. 1970, at 31.

${ }^{15}$ This sometimes raises a delicate policy problem in that a persistent necessity to seek overline aid from the city correspondent bank is evidence that the country bank 
Various forms of consultation services constitute an important part of the package. For example, advice and interpretation of pertinent and complicated laws and regulations are made available. Correspondents review money market developments, make recommendations on the purchase and sale of securities, execute the transactions and then provide for safekeeping of the securities. ${ }^{16}$ Likewise, the rapid expansion of American business into foreign markets has presented both the opportunity and the necessity for adding new services to the correspondent package. ${ }^{17}$

The exchange of inside information renders the correspondent relationship highly confidential. A close relationship is further engendered by the country bank's frequent reliance on its correspondent for counseling on officer and personnel recruitment, advice on operations methodology and guidance on executive training. ${ }^{18}$ Personal relationships frequently emerge; for example, because of regulations limiting the amount a bank may lend to an officer or employee, correspondents sometimes assist in loans involving larger amounts. ${ }^{19}$ This personal element may seemingly be trivial but nevertheless constitutes an important element in maintaining the account. Thus city bankers help country bank executives by getting everything from choice theater tickets to finding a "buyer for a herd of elephants acquired through default."20

Recent years bear witness to a mushrooming innovation in the character and scope of the service offerings, ${ }^{21}$ much of which

customers have outgrown the capacity of local banks and therefore should be passed on to larger institutions capable of satisfying their needs. D. HAYES, BANK LENDING Policies 101 (1971). Sometimes the loan flow goes in the opposite direction. Knight discovered that when local pressures for credit are low, country banks not infrequently purchase from or participate in loans with correspondents, with the profit often exceeding that possible on money market securities. Knight, pt. I, supra note 12, at 5 .

${ }_{16}$ One study even placed safekeeping of securities as the second (after check clearing) most important correspondent service. Speaking Frankly on Correspondent Banking, supra note 11 , at 36 .

17 "The way the world continues to shrink, many more banks will find themselves involved in export-import financing. They'll either have to inform themselves, or turn to a correspondent." Morris, New Emphasis on Correspondent Banking, 53 Burrougrs Clearing House, May 1969, at 19. RePORT ON The CoRRespondent Banking System, supra note 13, at 5-6; Strachan, Not in It? You May Be Soon, BANKING, July, 1972, at 46.

${ }^{18}$ McClain, supra note 9, at 966; Boushall, Correspondent Bank Service, THE SouTHERN BANKER, Aug. 1945, at 105 . One banker described the close relationship in these terms: "[I]n the event of a partial or general walkout of a country bank's personnel ... the correspondent bank, upon receipt of a phone call, would supply the stricken bank with sufficient experienced help to run the affairs of the bank until normalcy was restored." House Comm. Banking and Currency, Subcomm. ON Domestic Finance, Correspondent Relations: A SuRvey of Banker Opinion, 88th Cong., 2d Sess. 33 (Comm. Print Oct. 21, 1964) [hereinafter cited as Correspondent Relations].

${ }_{19} \mathrm{~K}$. FinNeY, supra note 10 , at 14.

${ }^{20}$ Id.; E. REED, supra note 9, at 29.

21 Keitt, Correspondent Bankers Enter Transition Period, AM. BANker, Dec. 18, 1970, at 34, col. 1. See generally 1970 Correspondent Banking Survey, AM. BANKER, Dec. 18, 1970, at 
is attributable to new technology and the increasing sophistication of bank management and bank customers. Another reason is the increasing vigor of the competition among city correspondents to get country bank deposits. ${ }^{22}$ A rise in the "real" value of the interbank deposit input, along with the general scarcity of loan funds, ${ }^{23}$ has made entry into the correspondent banking business more profitable, thereby putting additional pressure on city correspondents to look for new ways of both satisfying present accounts and attracting new business. ${ }^{24}$

The banking industry's break from a tradition of competitive moderation is reflected in the composition of the service package. ${ }^{25}$ Banks now venture aggressively into new fields in head-to-head competition with firms operating independently of bank affiliation. ${ }^{26}$ One result is that the correspondent service package has been enlarged considerably and now includes a greater component of heretofore "nonbanking" services such as auditing, electronic data processing, location studies and cost analysis. ${ }^{27}$

The payoff from correspondent banking can extend well beyond the immediate benefits from the services-deposit exchange. City banks recognize that present cooperation with country banks can serve as a prelude to absorbing the accounts

8-71; How Correspondents Look at Loan Participations, BANKING 20, 50 (1973).

${ }_{22}$ Sandidge, Correspondent Services Tied to Reliability, Innovation, AM. BANKER, Dec. 18, 1970, at 61, col. 1; Tyng, Correspondent Balances: Hardest Working Deposits, 48 BurRouGHS Clearing House, Jan. 1964, at 32; see also Oxford, Attracting Correspondents, 55 Burroughs Clearing House, Aug. 1971 , at 28.

${ }^{23}$ See note 81 infra \& accompanying text.

24 Domestic interbank balances at large commercial banks (which hold almost $90 \%$ of the total) were fairly slow-growing in size until about 1966 . From an average of about $\$ 9$ billion in the late 1940's they rose to around $\$ 11$ billion in the mid-1950's and to about $\$ 12$ billion in the early 1960 's. This increase of about $30 \%$ compares with a growth in total commercial bank deposits of over $125 \%$ in the period. Since 1966, however, growth has been very rapid, from $\$ 12.4$ billion in late 1965 to $\$ 18.1$ billion in early 1970 . Knight, pt. I, supra note 12 , at $7-8$.

According to Knight,

[t] he growth in correspondent accounts is remarkable because during this period interest rates rose to the highest levels in nearly a century and banks experienced very strong demands for loans. Contributing factors to the growth appear to have been the increasing need for correspondent services including loan participations, the general tendency for correspondent banks to analyze the profitability of individual accounts more closely, and the sharp rise in float Id. 8 . associated with Eurodollar transactions.

By the end of 1972 large bank interbank deposit balances were up to $\$ 22.7$ billion, again apparently reflecting the same factors as noted earlier by Knight-i.e., the growth in services sold to the country respondent bank (including a greater wealth of the nonbank and bank-related services) along with closer views of deposit crediting in account analysis procedures. 59 FED. REserve Bull., Feb. 1973, at A 29.

25 For a discussion of the philosophy of "honest and above "board" cooperative competition that formerly prevailed in banking, see G. FISCHER, AMERICAN BANkING StrUCTURE 253-55 (1968).

${ }^{26}$ See note 99 infra.

${ }^{27}$ See note 110 infra. 
of those businesses that eventually outgrow the resources of the local bank. ${ }^{28}$ Contact with the country bank's board of directors is a fertile source of nonbanking business. ${ }^{29}$ Moreover, a harmonious correspondent banking relationship can provide the city bank with the inside crack at acquiring the country bank should the opportunity arise. ${ }^{30}$ The more accounts a correspondent can plug into fixed cost items like computers, back-up equipment, and security, the greater the economies of scale. ${ }^{31}$ The ancillary benefits are not one-directional in that from time to time city correspondents direct new business to country accounts through loan and depositor referrals. ${ }^{32}$

Correspondent banking is not clearly dichotomized into "country" and "city" bank categories; instead the system is structured in a pyramid configuration whereby moderate sized institutions normally play a double role by supplying services while themselves relying on larger banks for correspondent aid. ${ }^{33}$ Likewise, depending on its size and needs, each country bank is likely to have a correspondent in different markets. ${ }^{34}$ Moreover, while within a particular city market country banks typically rely on a single city bank for services, they sometimes maintain dormant balances in other banks. ${ }^{35}$

\section{B. Barter Configuration of Correspondent Banking}

Prices for correspondent banking services are established through the barter of interbank deposits for the service package. This pricing convention originated under laws, still applicable to non-Federal Reserve member banks, that made it possible to include authorized correspondent deposit claims as part of reserve requirements. ${ }^{36}$ Three factors have caused the barter method to persist beyond its historical underpinnings: the banking industry's continued and heightened dependence on deposits

${ }^{28}$ D. Hayes, Bank Lending Policies 101 (1971); see Participation Loans, Banking, Jan. 1958, at 50. See also Knight, pt. II, supra note 14 , at 16 .

${ }^{29}$ See City Banks Lure Country Dollars, Bus. WEEK, Oct. 24, 1959, at 56.

30 Nadler, Three Score Years of Correspondent Banking, Banking, July 1968, at 54-55.

31 Sullivan, Correspondent Banking: $A$ City Correspondent Banker's View, Banking, Nov. 1972 , at 25.

32 RePort on the Correspondent Banking System, supra note 13, at 4; K. Finney, supra note 10 , at 17 .

${ }^{33}$ See Phillips, Competition, Confusion and Commercial Banking, J. Finance, Mar. 1964, at 32,42 .

${ }^{34}$ See A Report on the Correspondent Banking System, supra note 13 , at 1.

${ }^{35} \mathrm{E}$. REED, supra note 10 , at $122-23$. It is typically only the larger banks (over $\$ 50$ million in deposits) that maintain more than one account in a single commercial center. Lawrence \& Lougee, Determinants of Correspondent Banking Relationships, 2 J. MONEY, CREDIT, \& BANKING 358, 368 (1970).

${ }^{36}$ See K. FinNey, supra note 10, at 16. 
for growth and future profits; ${ }^{37}$ the fact that deposits have public relations value as an accepted indicator of bank size; ${ }^{38}$ and the legal prohibition against payment of interest on demand deposits. $^{39}$

Under the barter system interbank deposits constitute the measure of the "value" of correspondent services. ${ }^{40}$ Adherence to this system generates considerable criticism, with general agreement among the critics that the principal flaw is that neither party to the exchange has access to real cost figures. ${ }^{41}$ Country banks are unable to determine if they get full credit for their deposit balances, while city correspondents often have difficulty in convincing country bank customers that the service package warrants higher balances. ${ }^{42}$ Finally, price obfuscation makes it difficult to form judgments on the effectiveness of resource allocation in terms of the entire banking industry. ${ }^{43} \mathrm{On}$ this point primary concern is over the ease with which the level of required interbank deposits can be manipulated by city banks so as to disguise price concessions or outright price discrimination among customer country banks.

Recognizing the above defects, inspired by greater profit consciousness, and aided by advances in technology, banks have developed account analysis techniques for pricing services to individual customers. The essential purpose of account analysis is to enable correspondents to determine whether the interbank deposits received for services are adequate; if not, the country bank can be assessed the difference either in fees or requests for additional balances. But even though advances have been made in measuring the value or profitability of individual accounts, these new techniques remain vulnerable to some of the old defects. ${ }^{44}$ At the same time, efforts to convert to a general system

37 "Even today there is good reason for larger banks to want correspondent balances and to seek them out without initial regard as to their profitability. For in today's tight money market, any demand deposits at all are considered as a blessing." Nadler, supra note 30, at 55. See generally Mellon, The Future of Demand Deposits at Big City Banks, Bankers Mag., Autumn 1968, at 11 .

${ }^{38}$ How to Compensate Correspondents, Banking, Mar. 1973, at 60, 67.

${ }^{39}$ Greenbaum, Correspondent Banking, in INNOvations IN BANK MANAGEMENT 135, 144 (P. Jessup ed. 1969).

${ }^{40}$ See CoRrespondent Relations: A SuRvey of Banker Opinion, supra note 18 , at 10; see also Knight, Correspondent Banking: Account Analysis, FED. RESERvE BANK OF KANSAS City Monthly Rev., Dec. 1971, at 16 [hereinafter cited as Knight, pt. III].

"1 CoRrespondent Relations: A SURvey of Banker Opinion, supra note 18, at 10; see also Carr, Pricing Correspondent Banking Services, Bankers MAG., Summer 1967, at 65; Nadler, The Coming Change in Correspondent Relationships, BankInG, Apr. 1966, at 45.

${ }_{42}$ Correspondent Relations: A Survey of Banker Opinion, supra note 18, at 10; see also Knight, pt. I, supra note 12 , at 6 .

${ }_{43} \mathrm{Knight}$, pt. III, supra note 40 , at 17.

${ }^{44}$ See notes 166-69, 172-75 infra \& accompanying text. 
of assigning explicit fees to most major services have been consistently rebuffed by bankers. ${ }^{45}$

Continued reliance on interbank deposits as the expression of value has two ramifications germane to this Article. First, the scope of antitrust inquiry is substantially expanded. The use of a barter mechanism means that two relevant product markets are involved, a result further complicated by the fact that one of the product markets-correspondent services-is quantified and measured by the other-interbank deposits. Moreover, since city and country banks face off as both buyer and seller, the arrangement has overtones of both "forward" and "backward" integration. The city correspondent bank reaches backward to obtain a raw material, deposits, or, by gaining access to a market for its services, integrates forward. The country bank moves backward and taps a source of basic services which are used to service local customers; at the same time it moves forward to acquire an outlet for interbank deposits.

A second complication affects evaluation of market power. Under the barter method the outer ceiling on supply of the pricing proxy-deposits-is largely determined by central banking policy. ${ }^{46}$ Monetary policy, by influencing interest rates and loan levels, affects loan demand and loan participations. Thus the issue of the extent to which one of the parties to the barter may have an advantage of market power is influenced by the interplay of external regulatory forces with normal supply and demand pressures. ${ }^{47}$

${ }^{45}$ In one survey, less than $6 \%$ favored a fee system; a later survey revealed that $8 \%$ were in favor of a change to a straight fee system. The resistance to change is attributable to: (1) the fear by non-Federal Reserve member banks, which can charge correspondent balances against reserve requirements, that costs of servicing country banks would increase, (2) fear that the costs of services would be set arbitrarily, and (3) the attitude of correspondent bank officers that their primary function is to generate deposit balances. Knight, pt. III, supra note 40 , at 17 . Nadler concludes that country banks reject a fee system because under the present system "the balances are negotiable and of ten can be well below the amount that would be necessary to compensate the correspondent fully for services rendered." Nadler, supra note 30, at 46. See Correspondent Relations: A SURVEY OF BANKER OPINION, supra note 18 , at 10 .

${ }^{46}$ See note 55 infra; see generally L. Chander, The Economics of Money and BANKING 191 (1964).

${ }^{47}$ Thus, in a form of mirror image, there are 2 products bought and sold: interbank deposits and the "package" of correspondent banking services. Figure 1 (see page 374) represents an oversimplified illustration of the basic demand function of the city correspondent for interbank deposits within a market. Figure 2 (see page 375 ) depicts the hypothetical demand function of the country respondent for correspondent banking services. The supply functions are represented by the dashed lines in these diagrammatic illustrations. In Figure 1 the static demand function, $x=\phi(p)$, would be monotonically decreasing (that is, as price decreases, the amounts demanded would increase) and have a form depending on a number of parameters, such as customers' loan demands, interest rates both on customer loans and on alternative investment opportunities, the availability of alternate deposit sources, projected future loan demands and investment profitability. These parameters would be fixed for any one demand function, and any change in their value would, of course, shift the position of the demand curve. 


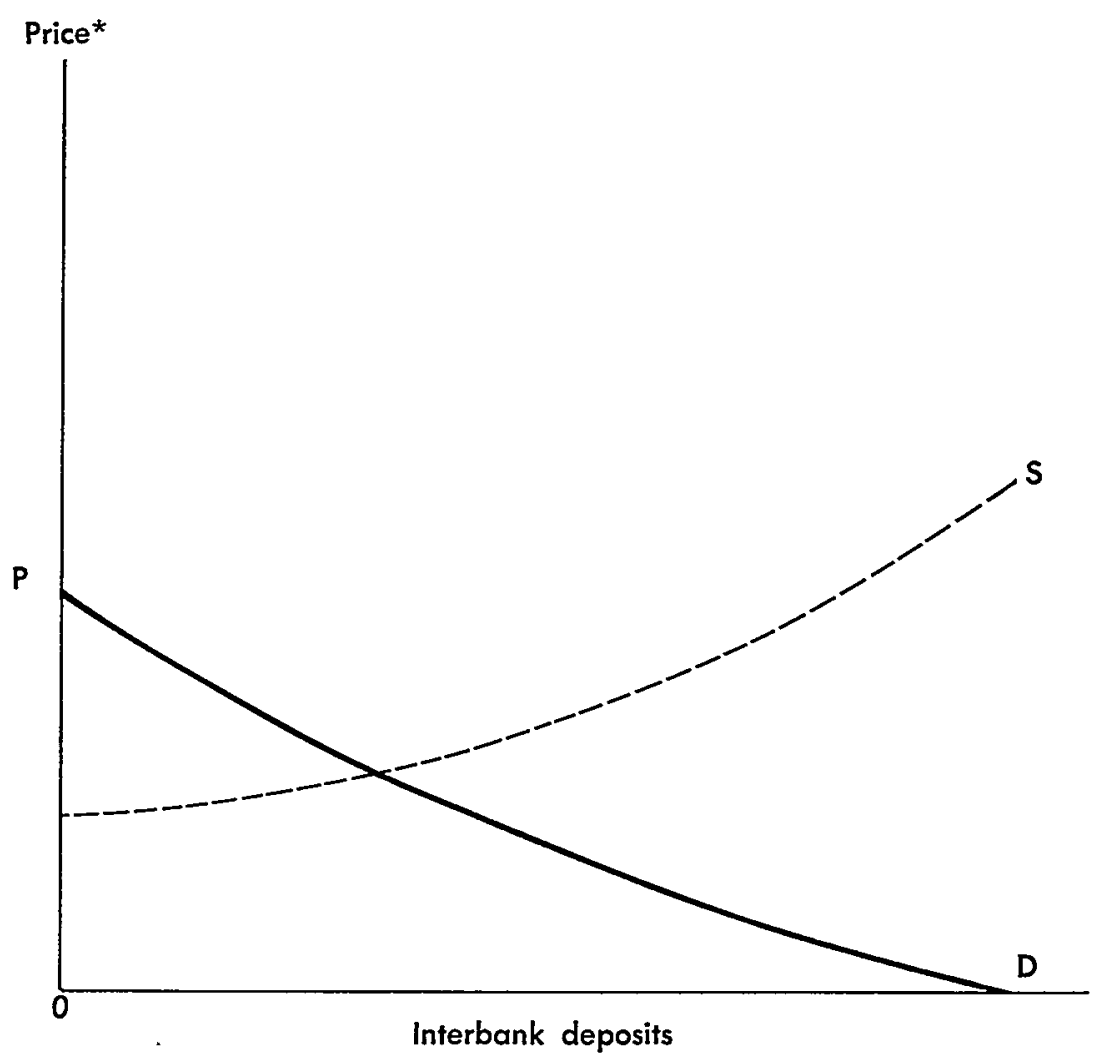

FIGURE 1 


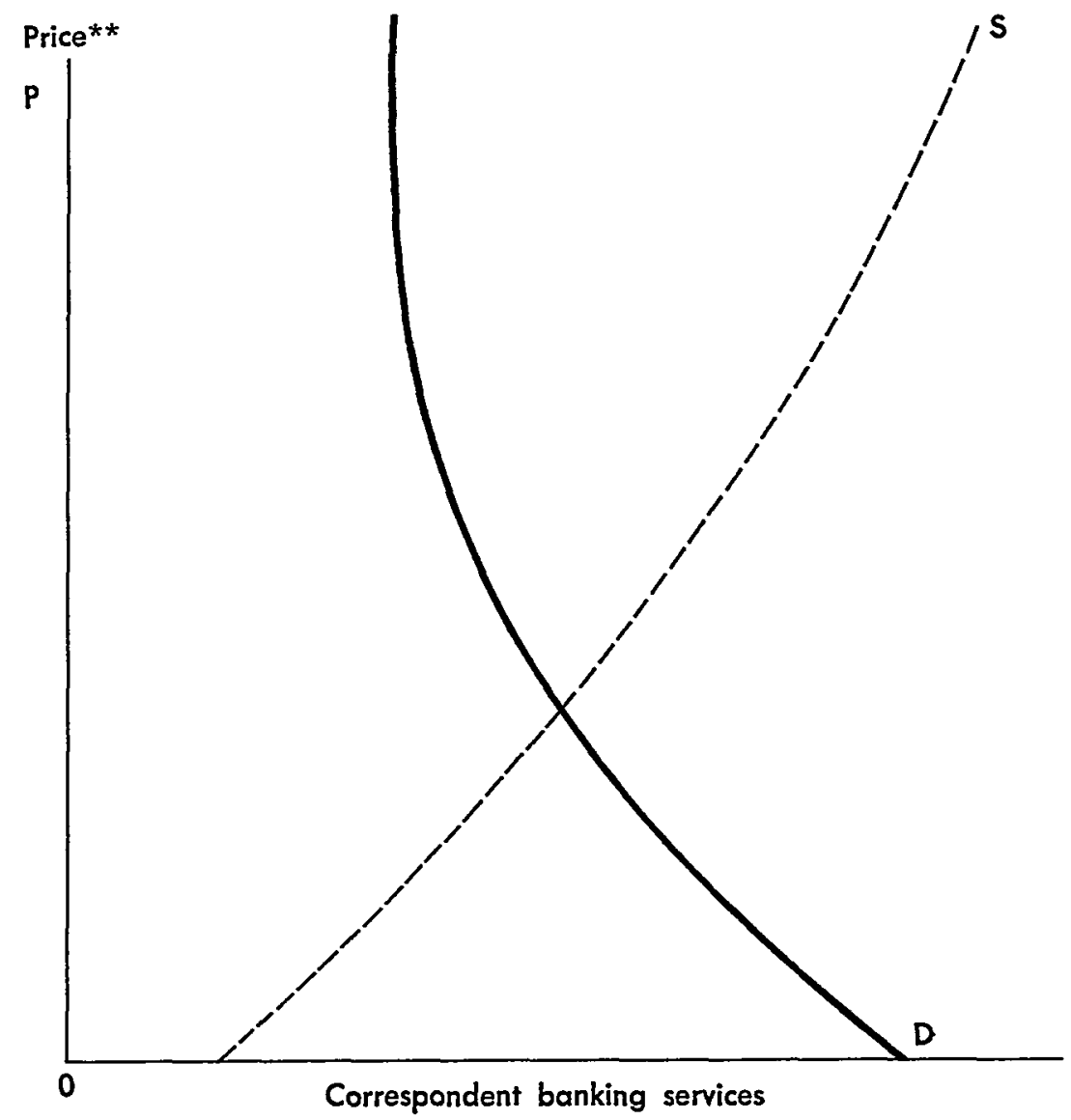

FIGURE 2 


\section{PResence AND Location of Market Power}

The source and vigor of market power in the correspondent banking relationship are important underpinnings to an antitrust evaluation. One of the reasons for proscribing vertical mergers is that they serve as a conduit for spreading horizontal market power from one market level to another. ${ }^{48}$ Vertical integration can also constitute a device for crossing market power from one product line to another. Whether these and other effects will occur can best be determined by consideration of the basic configurations in which market power is manifested in correspondent banking.

Possession of market power enables a firm to "behave persistently in a manner different from the behavior that a competitive market would enforce on a firm facing otherwise similar cost and demand conditions." 49 Market power is a fluid concept embracing a continuum beginning with the theoretical and nonexistent state of perfect competition and extending through levels of increasing leverage to the ultimate point of monopoly. Acknowledging that most firms possess "some degree of market power," 50 industrial organization economics advises that the magnitude of the deviation from perfect competition can best be measured by examining first market structure ${ }^{51}$ and then indicators of performance..$^{52}$ Neither technique can identify the extent or

Presumably, the supply of technical banking expertise, loan participation funds and check clearing equipment and personnel would place some outer limit (at the unrealistic "price" OP* in Figure 1) on the city correspondent's ability to "buy" interbank balances in return for services. But as price decreases, the quantity of balances demanded by the city correspondent would rise sharply until the "saturation" point is reached (as, for example, during the reserve-flooded period of the early 1930 's).

On the other side of the barter deal, the country bank's demand for correspondent services (Figure 2) would be similarly continuous and monotonically decreasing. But the demand curve in Figure 2 could be more steeply downward sloping than in Figure 1, since the saturation point of services demanded is reached more quickly, while a certain almost irreducible level of clearing and loan participation services is required for the survival of the small country respondent. Empirical testing would be required, of course, to state more accurately the presumed shape of these functions over a period of time.

${ }_{48}$ P. AREeda, ANTITrust ANalysis 521-22 (1967); C. Kaysen \& D. Turner, ANTItrust Policy: AN Economic AND Legal ANALYSIS 75 (1965).

${ }^{49} \mathrm{C}$. KAYSEN \& D. Turner, supra note 48 , at $121-23$; see F. Scherer, Industrial. Market Structure and Economic Performance 10 (1970).

${ }^{50}$ C. KAYSEN \& D. TURner, supra note 48 , at 16 .

51 Many economists deem examination of market structure of first priority because it involves reference to "conditioning" factors which produce "results" or performance. $R$. Caves, American Industry: Structure, Conduct, Performance 17 (1967); J. Clark, Competition as a DyNamic Process 421 (1961).

52 By omitting discussion of "conduct," the analysis follows generally the style adopted by Kaysen and Turner. C. KAYSEN \& D. TuRNER, supra note 48 . Conduct is deemed to be a middle link between structure and performance. "[S]tructure is systematically associated with or determines conduct; and conduct, as determined by structure, determines performance." J. BAIN, InDuSTRIAL ORGANIzATION 329 (2d ed. 1968). Conduct is, however, "often an unobservable phenomenon," and many economists question 
location of market power in the correspondent relationship with total reliability. On the other hand, an evaluation of correspondent banking within the parameters of each test identifies some distinctive conceptual problems that confront analysis and, at the same time, reveals the gaps in the present state of the empirical data. The inquiry also suggests a broad and tentative set of guidelines for making findings on market power.

\section{A. Market Structure}

Following the lead of economists, courts deem certain structural configurations that occur in markets, such as concentration and condition of entry, sufficiently probable indicators of the presence of market power to allow theoretical predictions as to how such power can be expected to operate. ${ }^{53}$ In the most effective context, a court or agency "may presume [subject to rebuttal] that the market operates in accord with generally accepted principles of economic theory . ..."54 For example, given a setting in which an oligopolist confronts a buyer operating from a competitive market, a presumption exists that market power in some magnitude is tilted in favor of the oligopolist. The problem posed by correspondent banking is that it does not fit into a structural frame of reference capable of satisfactorily delivering forecasts. The structural theory most suitable, bilateral oligopoly, applies with such indefiniteness as to discourage resort to the use of presumptions.

The reciprocal barter relationship between city correspondent and country bank is generally conducted within a bilateral oligopolistic market. Since regulations and central banking policy restrict the supply of interbank deposits, ${ }^{55}$ the number of entrants into banking, ${ }^{56}$ and mobility, ${ }^{57}$ both sides to the barter

its validity as a "meaningful explanation of performance," P. AsCH, ECONOMIC THEORY AND THE ANTITRUst Dilemma 163 (1970), and its empirical reliability, J. BaIN, supra at

329. The flexible range of the Kaysen and Turner approach surmounts these criticisms:

Thus it is not useful to attempt to maintain too rigid a distinction between structure and conduct; structure in a broad sense can be taken to include both structure proper and conduct. In this broad sense, the structure of a market, from the point of view of a particular firm, comprises the circumstances external to that firm which condition its decisions, including the characteristic conduct of other firms in the market.

C. KAYSEN \& D. TURNER, supra note 48 , at 60 .

${ }_{53}$ Austin, $A$ Priori Mechanical Jurisprudence in Antitrust, 53 Mins. L. REv. 739 (1969).

${ }^{34}$ FTC v. Procter \& Gamble, Co., 386 U.S. 568, 598-99 (1967) (Harlan, J., concurring).

${ }_{55}$ D. Hodgman, Commercial Bank Loan and Investment Policy 145 (1963).

${ }^{56}$ Davis, Banking Regulation Today: A Banker's View, 31 Law \& ContemP. Prob. 639, 641 (1966). (1965).

Horvitz, Stimulating Bank Competition Through Regulatory Action, 20 J. FinANCE 1, 3-5 
operate within oligopolistic market conditions. ${ }^{58}$ For the same reasons, the parties generally are unable to attain the status of true monopolists or monopsonists.

The presently inchoate state of theories on bilateral oligopoly renders difficult, if not impossible, predictions of pricing behavior which are sufficiently solid to support presumptions on market power. 59 As Professor Scherer summarizes: "When power in sellers' markets is countered by power in buyers' markets, almost anything can happen."60 It is not known whether parties to a transaction attempt to maximize their individual profits, thereby ignoring their interdependence in their respective markets, or whether they confront each other on a unified basis and engage in group negotiations to maximize joint profits. ${ }^{61}$ Under either possibility there exists a wide range of possible effects on pricing. ${ }^{62}$ Lack of precision also extends to the critical issue of whether the balance of power between buyer and seller can be expected to shift with changes in the final consumer demand schedule. ${ }^{63}$

To further cloud matters, correspondent banking presents a type of bilateral oligopoly generally unexplored by economic literature. Bilateral oligopoly refers to an oligopolist-oligopsonist confrontation over a single product. Correspondent banking, involving as it does a barter of interbank deposits for services, is a "mirror" form of bilateral oligopoly; each party is both oligopolist and oligopsonist. As a final problem, the quantity demanded or supplied by both oligopsonist and oligopolist is not

${ }^{58}$ See Phillips, supra note 33.

59 J. BAIN, supra note 52, at 368-72; F. SChERER, supra note 49, at 239-52.

$60 \mathrm{~F}$. SCHERER, supra note 49 , at 252 .

61 Bain concludes that "group negotiations do not generally appear." J. BAIN, supra note 52 , at 369 .

62 See W. Carter \& W. SNavely, Intermediate Economic Analysis 249-50 (1961). Banking is further complicated because changes in the mutually acceptable rules of the game with respect to pricing, adaptation of existing pricing conventions, or a regulatory resolution of the problem may inadvertently influence strongly the level of prices. For a discussion of recent changes, see Evolution of the Payments Mechanism, 58 FED. RESERve Bull. 1009 (1972).

${ }^{63}$ F. Scherer, supra note 49, at 246 ; J. BAIN, supra note 52 , at $369-70$. It is obvious that interbank balances held by the city correspondent present only the intermediate product in the production chain. The input of these balances is used ultimately to produce consumer goods at retail (loans, of varying degree of risk and yield). If banks attain oligopsony power and succeed in buying deposit inputs at lower price, there is still the question whether price savings are passed on to the final consumer, the borrower. If, instead, the price saving tends to be trapped within the production process in what has been labelled by Scherer a "myopic chain monopoly," the result is a public welfare or distributive loss.

In similar vein, any failure of the city clearing banks to pass back to the country banking consumers any efficiencies resulting from automation or joint use of clearing facilities in immediate payment zones will also result in distributive losses within the production process of banking. 
dependent upon a finite set of other quantities but upon mutually interacting and variable functions. ${ }^{64}$

\section{B. Indicators of Performance}

An evaluation of market power may be conducted by reference to some of the basic indicators of performance: prices and costs, along with output, capacity, and demand. ${ }^{65}$ Here the inquiry is essentially empirical: "Market performance describes the actual behavior, in terms of certain economic criteria, of the firms in the market." 66 Because of the uncertain mechanism by which price and costs in the market for correspondent banking services are determined and the paucity of empirical insights into the barter process, performance analysis is also unenlightening.

Generally speaking, when demand is stationary and a firm's price exceeds its longrun average costs, there is a strong likelihood of poor resource allocation, inefficiencies or the exercise of some magnitude of market power. ${ }^{67}$ As to correspondent banking, the significance of data on pricing and profits (the latter considered a "fairly good measure of longrun price-cost relations" 68 and thus an indicator of the degree of discretionary pricing power) is obfuscated by the difficulty in distinguishing

64 The reciprocal marginal revenue curves here are shifting as a result of continuously changing "real" values of interbank deposits and the correspondent service package. Therefore, if market power exists, reciprocal outputs $D_{1}$ (interbank deposits) and $C_{s}$ (correspondent services) must each depend upon the form of some interacting variable marginal revenue functions, i.e., upon supply functionals, as follows: $D_{1}=f\{\phi\}$; $\mathrm{C}_{s}=\mathrm{g}\{\gamma\}$; and $\mathrm{D}_{\mathrm{I}}=\mathrm{h}\left\{\mathrm{C}_{\mathrm{s}}\right\}$.

The market price of correspondent services will also vary continuously and may be represented by some time function $p(t)$. The demand of the country respondent for the correspondent service package will incorporate this "speculative" element geared to anticipated future, as well as present price and customer requirements; this demand by country respondent $\left(d_{c}\right)$ may then be described by the following demand law: $\mathrm{d}_{\mathrm{c}}=\phi\left\{\mathrm{p}(\mathrm{t}), \mathrm{p}^{\prime}(\mathrm{t})\right\}$. The city correspondent's rate of profits per unit of time, if it produces an output $C_{s}$ per unit of time and sells it at the price $p(t)$, may be shown as $C_{s} p(t)-\pi\left(C_{s}\right)$, where the cost of production is given by $\pi\left(\mathrm{C}_{s}\right)$. The rate of profit will depend on price and the rate of change of the price at this time (expressed in terms of the changing value of interbank deposits). The problem then is to find the functions $p(t)$ which maximize the value of $u=\int_{t_{0}}^{t_{1}}\left\{C_{B} p-\pi\left(C_{B}\right)\right\} d t$, where $u=$ total profits and $C_{s}=\phi\left(p, p^{\prime}\right)$ and where the boundary conditions give $p=P_{0}$, if $t=t_{0}$ and $p=p_{1}$ when $t=t_{1}$. For this, for each side of the barter transaction, we put $\frac{d u}{d p}=0$ subject to $\frac{d^{2} u}{d p^{2}}<0$, and determine prices of each expressed in terms of the other from the resulting equations. For other applications of supply functionals, see R. Allen, Mathematical ANALYSIS FOR ECONOMISTS 533-36 (1967).

65 C. KAYSEN \& D. TuRnER, supra note 48 , at 58-59. See also J. Dirlam \& A. Kahn, Fair Competition: The Law and Economics of Antitrust Policy 35-42 (1954); P. Asch, supra note 52, at 164-66. The term "market performance" has wider connotations than used in this article. See R. CAves, supra note 51, at 93-110.

${ }^{66}$ C. Kaysen, United States v. United Shoe Machinery Corporation 17 (1956).

67 C. KAYSEN \& D. TURNER, supra note 48 , at 64.

${ }^{68}$ Id. 63; see J. BAIN, supra note 59, at 375 . 
"real" from "ostensible" prices. For example, prices paid for interbank deposits, expressed in terms of units of services furnished by the city correspondent bank, in many instances have not been adjusted for usable "float", i.e., uncollected balances. ${ }^{69}$ If immediately available for investment or other use by the depositing country bank, the uncollected balances represent, as an element of price, an interest-free short term loan. ${ }^{70}$ Likewise, increases in payments for interbank deposits may be hidden in lower requirements for compensating balances, in excess of average working balances, to be paid by the country bank or its customer on loan participations. ${ }^{71}$ Other price obscuring features, such as lower collateral requirements, can be used in loan participations. Finally, the city bank can, without altering the level of required interbank deposits, include new or improved "free" correspondent services in the package, or the customer may be billed at rates below costs.

Consideration of output, capacity and demand raise different problems. Ideally, the level of output should be responsive to consumer demands, ${ }^{72}$ and the ability to manipulate that level to gain excessive profits is a sign that a firm possesses market power. In correspondent banking, questions of the character of output, capacity and demand are, to a large extent, resolved by externally imposed regulatory forces and inflexible public needs. On the other side of the barter, the limit on deposits available for "sale" or transfer between banks is fixed jointly by central banking policy and the public's credit demands, not by unfettered pricing or by the participants in the transaction. At the same time, especially when customer loan demands are high, the bank's demand for deposits may be fairly insatiable, whatever the real price.

\footnotetext{
${ }^{69}$ Float reflects uncollected balances (amounting at the time of the 197I Federal Reserve Bank of Kansas City survey to $42 \%$ of the total ledger balances) due to other banks. Knight, pt. III, supra note 40 , at 8 . These balances represent the dollar amount of cash and noncash items correspondents have received for clearing but for which they are unable to obtain immediate credit because of transfer and other delays. City banks, under account analysis, now usually deduct uncollected balances-"float"-in determining the earnings value of an account. See Knight, The Impact of Changing Check Clearing Arrangements on the Correspondent Banking System, FED. RESERvE BanK OF KANSAS CitTY MONTHLY REv., Dec. 1972 , at 14 n.1, 15 n.3.

70 The more general practice now, however, is for the city correspondent to "freeze" the balances against withdrawal prior to collection. The city correspondent will, at the same time, always grant immediate ledger credit to the bank of deposit which can immediately satisfy legal reserve requirements of state nonmember banks and free equivalent amounts of cash for investment by these nonmember banks. See id.

${ }^{7}$ Broadly speaking, the term "compensating balances" describes the deposit balances a customer must hold with the lending bank as a condition to receiving credit. If compensating balances exceed "working" balances, the excess constitutes an oblique means of increasing the interest rate on the loan. Austin \& Solomon, The Antitrust Implications of Compensating Balances, 58 V.. L. REV. 1, 10-11 (1972).

${ }_{72}$ C. KAYSEN \& D. TURNER, supra note 48 , at 66 . See J. BAIN, supra note 59 , at 382-85.
} 


\section{Leverage Factors Associated with Correspondent Services}

Interbank demand deposits are fungible; each unit may be replaced by another unit without altering the recipient bank's growth, loan and investment potential. Moreover, because the overall supply of this raw material is largely dependent upon external forces, its availability will not be increased in response to changes in price. These factors are absent on the services side of the barter; their absence raises different leverage considerations calling for separate treatment.

Because of a dependence upon the state of buyer demand schedules for the separate elements of the package, correspondent services vary in potential capacity to confer leverage. Generally, loan participations stand high in desirability. ${ }^{73}$ The same market imperfections creating a scarcity of deposits-the raw material for lending-have a fallout effect by putting a premium on ready access to overline accommodation. There is an additional factor that bears on market leverage; generally overlines permit country banks to overcome limits on lending capacities to satisfy local customers. Consequently, the failure of a correspondent bank to respond to these needs of the country bank on a quick and satisfactory basis would likely result in the loss of a valuable customer.

Check clearing is probably towards the other end of the scale; it is a necessary function but has no scarcity element. ${ }^{74}$ Any number of medium-sized banks can supply check clearing services. The congeries of other correspondent services are dotted all over the scarcity scale, leaving the purchaser with a number of options, including splitting purchases between bank and nonbank sources.

As a practical matter, the option of obtaining services from different sources may not be feasible. The use of interbank deposits as payment tends to dissuade the country bank from splitting up purchases among several sources. ${ }^{75}$ There would be difficulty, expense and loss of time in calculating the price for

${ }^{73}$ Knight, pt. III, supra note 40 , at 3 . The importance of overlines to the country bank is borne out by evidence that their availability is considered the "real test" of the relationship, with refusal by the city bank likely to lead to a shift to a new city bank, Linneman \& Meinster, $A$ Major Strain in Correspondent Relations, BAnking, Sept. 1970, at 50, 102. See also What Small Banks Want from Correspondents, BANKING, Nov. 1971, at 17.

${ }_{74}$ It is, however, a function considered to be standard in correspondent banking. See note 12 supra \& accompanying text. Clearing facilities may achieve a form of scarcity status where access is allocated under burdensome terms.

75 "Over-all [country banks] seemed more interested in the total relationship than in the price of a specific service." Linneman \& Meinster, supra note 73, at 50. Likewise, a country bank may be locked in because of a loan participation. Roundtable, Banking, Dec. $1972,46,55$. 
each service. ${ }^{76}$ Furthermore, splitting up the sources may, result in obtaining less of the free services that city correspondents typically provide completely faithful customers. Moreover, any desire for spreading business among city correspondents may be tempered by the disinclination to endure the costly process of establishing new confidential relationships. Finally, a reluctance to risk offending longstanding suppliers may constitute a formidable deterrent to scattering purchases.

Technology is becoming an increasingly important influence in determining the weight of market leverage. Technological advances have increased significantly the banking industry's dependence on sophisticated services-especially those associated with computers. This is particularly true for the small "general practitioner" bank which "is not the efficient operator [it] used to be because the various methods and legal technicalities of banking have become too complex for [it] to keep pace."77 Those banks that have ready access at reasonable charges to the techniques of modern competition will survive; those without will flounder or be absorbed by holding companies. ${ }^{78}$ Thus country banks may feel some of the bargaining leverage now derived from the city bank's dependence on interbank deposits slip away in the face of the necessity to tie in to modern services. ${ }^{79}$

\section{Tentative Guide to the Tilt of Market Power}

Conditions on the interbank deposit side of the barter-particularly the general condition of the credit market-constitute the most discernible source of information on the tilt of market leverage. It would be reasonable to assume that in times of extended credit restraint, some degree of market leverage is on the side of the seller of deposits. ${ }^{80}$ This is,

76 "The average cost of clearing a check may be calculated with some degree of accuracy, but the cost and value of an account referral or a request for information would vary greatly with the specific circumstances." Knight, pt. III, supra note 40, at 17.

${ }^{77}$ Correspondent Relations: $A$ Survey of Banker Opinion, supra note 18, at 25. See Rust, Compruter Leasing and Correspondent Services, 85 BANKERS MoNTHLY, Nov. 15, 1968, at 33.

${ }^{78}$ One of the justifications for acquisition of small banks by holding companies is that new and innovative correspondent services have not been made available to country banks. Knight, pt. 1, supra note 12 , at 3 .

79 "Another aspect of this platform for innovation consists of a growing problem to the smaller, nonautomated, country banker. Because he lacks the volume levels and the requisite skills and experience to install a computer, he finds larger, automated banks posing a real threat to the customer ties he has developed over the years." Rust, supra note 77 , at 33 .

${ }^{80}$ As one correspondent bank responded to a question on the merits of a fee system: "But when money is as tight as it was during 1966 and 1970, balances are what we need most." White \& Sullivan, Two Ways of Looking at the Real Value of Correspondent Banking, BANKING, Nov. 1972, at 24, 42 . 
however, a fragile assumption that could only be verified by piercing the veil of unitary pricing.

Any persistent presence of usable float, concessions on compensating balances required for overlines, along with other favorable terms on overlines, would generally support a conclusion that market leverage resides with the country bank sellers of interbank deposits. Although difficult to quantify, an increase in these concessions could be interpreted as an increase in prices paid to the country bank for interbank deposits. Also worthy of scrutiny is the composition of the service package in terms of the way it is weighted as to the value of services in return for a given unit of interbank deposits. The greater the value of the services provided, the more likely it becomes that leverage is possessed by the supplier of the interbank deposits. Although less reliable because of difficulties of quantification, a final factor to be considered is the vigor of competition among city banks for interbank deposit accounts. Evidence of aggressive selling tactics and the marketing of new and innovative services at low cost would normally suggest that interbank deposits are at a premium.

The application of these guides to present conditions furnishes a framework for general observations. There is evidence of an ever tightening money market ${ }^{81}$ which enhances the value of interbank deposits. The financial press reports that competition among city banks for interbank deposits continues to be intense. ${ }^{82}$ Further indication of keen competition for the country bank business is that the range of services offered in return for deposits is being broadened.

Thus some justification exists for surmising that presently the balance of leverage is tilted in favor of the country bank sellers of interbank deposits. Whether this in fact describes market conditions remains unverified. For one thing, hard data is too sketchy and too shrouded in the uncertainty of the unitary pricing habit to support definite conclusions. The dependence of the country bank-particularly small independent banks-on valuable correspondent services for continued competitive integrity could neutralize any degree of leverage flowing from deposit

81 'The finance section headline in U.S. NEwS AND WORLD REPORT, May 28, 1973, at 94, captions present conditions in these words: "Tight Money, High Interest Rates-Who Will Get Hurt." The prime interest rate, a good indicator of credit conditions, finally eclipsed the record levels set in the 1969-1970 credit crunch and peaked for large business loans at $10 \%$ in September 1973. 59 FED. RESERVE BULl. A32 (1973).

${ }^{82}$ See Correspondent Banking-1972, AM. BANKER, Dec. 18, 1972, at 34, 36, 42, 48. 
scarcity. Another factor affecting a reliable overall impression is that in particular markets mergers between correspondent banks and local rivals may have reduced options and in the process reduced the bargaining power of the independent country banks.

\section{Possible Anticompetitive Effects}

United States v. First National Bancorporation, Inc., ${ }^{83}$ serves notice that application of antitrust law to correspondent banking involves confrontation with new problems. Much of what is either said, or not said, in that decision dramatizes the need to consider the possibility of making some adjustments in proscriptive standards to deal realistically with correspondent banking. In order to fully appreciate the gaps in that opinion and thus to be able to recognize the total dimensions of the antitrust problem, it is necessary to establish as a frame of reference an overview of the market effects that could, a priori, result from acquisitions of country banks by city correspondents.

The influence of a multilayered curtain of public regulations in banking bears directly on the discussion of competitive effects. Regulatory discretion over market entry (charter privileges and limits on mobility), ${ }^{84}$ along with management of the basic raw material, the supply of money, ${ }^{85}$ injects two factors into analysis. First, an inevitable consequence of artificial barriers to entry is a banking system composed of moderate to tight oligopolies. This system has confirmed the teachings of industrial organization theory ${ }^{86}$ by depositing a high degree of horizontal market power in banks. ${ }^{87}$ As a general proposition, therefore, a vertical merger carries the potential for the spread of market power from one market into another market. Second, as noted earlier, ${ }^{88}$ correspondent banking is likely to be conducted under conditions of bilateral oligopoly and thus raises the possibility that spreading effects will occur in both markets.

\section{A. Effects in the City Correspondent Market}

The most likely effect of such a vertical merger on competition among city correspondent banks is the elimination of a

83329 F. Supp. 1003 (D. Colo. 1971), aff'd by equally divided Court, 410 U.S. 577 (1973) (Powell, J., not participating).

${ }^{84}$ See note 56 supra.

85 See note 55 supra.

${ }^{86}$ See C. Kaysen \& D. Turner, supra note 48; R. Caves, supra note 51.

${ }^{87}$ Phillips, supra note 33 , at 32,42 .

${ }^{88}$ See notes $55-64$ supra \& accompanying text. 
source of competition between these banks. This is the standard concern over market foreclosure. ${ }^{89}$ In banking this assumes that an acquiring city correspondent bank would discourage or forbid its country bank affiliate from engaging in major correspondent activities with the acquiring bank's city rivals, ${ }^{90}$ thereby permanently sealing such rivals off from the bulk of that account. There is some evidence supporting this assumption; in the succinct words of one banker, "Blood is thicker than water."91

Inherent in the barter pricing mechanism is the potential for a double-edged foreclosure effect. Not only would city rivals be fenced out from a source of interbank deposits, but they likewise might lose the opportunity to sell a broad and growing spectrum of banking services to the affiliated country bank.

A second possible adverse effect is that the acquisition would establish a conduit for spreading market power. This would depend to a considerable extent on the state of the money market and the tone of central banking policy. If deposits and loans were in particularly scarce supply, acquisition of a country bank, with the accompanying access to scarce deposit raw materials, would transfer considerable power in the form of important buying leverage back to the city bank. City banks with extensive sources of interbank deposits would have a clear-cut advantage over rivals with fewer and less controllable sources. Availability of an assured stream of deposit inputs has in fact motivated acquisitions of banks in areas of growing population. ${ }^{92}$

An advantage to the acquiring city bank may result from a reduction of costs. The high cost and inconvenience of obtaining reserves through the federal funds markets or Eurodollar markets in time of credit restraint could be lessened by the availability of less costly interbank deposits. Similarly, the integrated correspondent bank may be free of some of the price shading (e.g., greater absorption of float ${ }^{93}$ ) utilized in attracting interbank deposits during times of credit restraint.

${ }^{89}$ See note 187 infra.

so In United States v. First National Bancorporation, Inc., 329 F. Supp. 1003 (D. Colo. 1971), the Government contended that: "Shortly after their acquisition agreement, First National Bank of Greeley shifted the substantial portion of its correspondent banking business, as measured by interbank demand deposits, from Colorado National Bank to First National Bank of Denver, Bancorporation's lead subsidiary bank." Plaintiffs PreTrial Proposed Findings of Fact and Conclusions of Law at 46.

${ }^{91}$ How Correspondents Look at Loan Participations, Banking, Feb. 1973, at 20,60 [hereinafter cited as Loan Participations].

${ }_{92}$ See F. Wille, FDIC Merger Policy 1970-72, at 10-12, Sept. 22, 1972. For a related discussion, see S. Talley, Developments in the Bank Holding Company Movement, Oct. 1972 (paper submitted to the Chicago Banking Market Conference).

${ }_{93}$ See note 69 supra \& accompanying text. 
The periodic appearance of easy credit does not undercut the impact of these market leverage effects. The money market is cyclical-credit restraint follows easy credit. Borrowers are fully sensitive to this phenomenon and plan accordingly. The usual hedge is to establish a durable credit relationship and assure first priority in periods of need or tight money. ${ }^{94}$ Borrowers are not prone to shop around when the money market eases and thereby risk antagonizing a supplier whose support will undoubtedly be needed in the future. Thus a city correspondent that can increase its loans during a period of monetary restraint by drawing upon extensive interbank deposits will probably be perceived by its new customers as having a permanent advantage over its less advantageously situated rivals and will therefore permanently retain the new business.

Finally, there is the possibility that market entry conditions in correspondent banking could be adversely affected. "Entry" in this context generally means the existing bank's additional cost and promotional effort (involving perhaps a new correspondent banking department) to attract customers desiring full-service facilities. Banks contemplating entry into full-service correspondent banking would have to satisfy three requirements: existing location in a center of economic activity; resource capabilities, including knowledgeable personnel and sophisticated electronic and check processing equipment; and the opportunity to obtain a sufficient quantity of country bank accounts to justify the costs of entry.

Even assuming that the first two requirements could be successfully hurdled, a potential correspondent bank might still be hesitant to enter the market if there already exists a moderate to high level of integration in the more attractive country bank markets. Barriers to entry could be further heightened by a "triggering" effect; confronted with a dwindling number of unaffiliated country banks and the concomitant loss of interbank deposits, correspondent banks could be expected to respond with increased efforts at further acquisitions.

\section{B. Effects in the Country Bank Market}

Anticompetitive effects in the country bank market could occur in waves. Initially, there would be an evaporation of

${ }^{94}$ Knight concludes: "Correspondent banks generally reported that their first priority [when monetary policies were extremely restrictive and bank liquidity was low] had been to satisfy the needs of long established correspondent customers ...." Knight, pt. II, supra note 14 , at 15 . 
shopping options in the city correspondent market, then the possibility of a country bank's being confronted with a local rival's first priority right to valuable service components from its parent correspondent, and, finally, efforts by the remaining unaffiliated country banks to seek out correspondent merger partners.

Because only a certain number of banks possess the size, resources, and expertise to engage in the complete range of correspondent banking activities, full service correspondent banking options are necessarily limited. Geographical considerations have a further narrowing effect because city correspondents normally function only out of economically significant areas. Under these conditions of limited options, a merger involving a local country rival and a potential city correspondent could have an adverse effect on the bargaining position of the remaining independent country banks.

The expectation of harmful effects from the elimination of a correspondent bank option rests on the assumption that remaining independent country banks will not want to deal with the parent of the acquired rival. Two reasons tend to support this assumption. First, there will be a serious concern over receiving second-best services, especially in regard to overlines. ${ }^{95}$ There may also be the recognition by independents that if they did engage in extensive business with a rival's parent, there would exist the possibility that confidential information would seep down to the local rival. ${ }^{96}$ The extent of the country bank's vulnerability would depend upon its own resources and, more importantly, the range of remaining options.

If the country bank chooses not to switch its correspondent business following the city correspondent's acquisition of a local rival, competition could be dampened in a less discernible way. A community of thought on banking practices may drift downward to both the newly acquired affiliate and those independent country banks continuing to deal with the parent correspondent bank. ${ }^{97}$ The greater the dependency of the country banks on the

${ }^{\mathbf{9 s}} I d$.

${ }^{96}$ Loan Participations, supra note 91 , at 60.

${ }^{97}$ Regardless of merger, this is a danger inherent in correspondent banking. Phillips, supra note 33 , at 32 . As holding companies enlarge the circle of formal and informal affiliations through correspondent banking, the possibility increases that a statewide linked oligopoly effect will surface where "[m]ultiple contact by the same banking leaders within a state, in progressively more of the state's banking markets, may serve to strengthen the lines of communication between them and increase the adherence to any pre-existing group competitive standards." Solomon, Bank Merger Policy and Problems: A Linkage Theory of Oligopoly, J. Money, CredrT \& BANkIng, Aug. 1970, at 323, 331. 
city bank, the more pronounced the spreading of uniform behavior in the country bank markets.

Subsidization effects are possible. For example, the city correspondent bank could channel generous portions of overlines to its affiliated country bank, while freezing out unaffiliated local banks. Country affiliates would also be assured of getting prime local referrals from the city correspondent, along with backup resources for seizing good potential branching opportunities within the local market.

Independent country banks are likely to be keenly aware that the elimination of an option tends to diminish their bargaining position vis-a-vis the remaining city correspondents. ${ }^{98}$ Moreover, those banks which shift to new city correspondents risk being dropped to a less preferred position on overlines, along with possibly incurring administrative delays and the inconvenience of transferring confidential records. If the universe of correspondent options is further reduced by subsequent mergers, the country banks will see in the future the spectre of having to deal with the city affiliate of a local rival. Confronted with this scenario, country banks will have added incentive to opt for a favorable merger arrangement with a correspondent.

\section{Crossover Effects into "Nonbanking" Markets}

Paying heed to the call of new technologies and repudiating longstanding inhibitions against engaging in "commercial" activities, banks now offer "nonbanking" services such as auditing, computer leasing and investment counseling, in direct competition with firms not associated with banks. ${ }^{99}$ Vertical integration by merger could furnish city correspondents with an opportunity to gain advantages over rival nonbank suppliers unrelated to efficiencies or competitive merits.

The danger of market crossover is inherent in correspondent banking. City correspondents can exploit a legal monopoly as to certain services (check clearing), the strategic advantage of experience and expertise in other areas (management and personnel counseling), and the subtle but strong ties of intraindustry affinities, to exclude nonbank affiliated rivals from access to servicing country banks. ${ }^{100}$ There is a natural tendency

${ }^{98}$ The reduction of shopping options and the dilution of bargaining power would be of critical significance in unit banking states where small independent banks are likely to depend heavily on correspondent services. See notes 212-16 infra \& accompanying text.

${ }_{99}$ See Correspondent Banking-1972, supra note 82, at 14, 22, 38, 42, 44; Goldberg, Multiple Bank Service Packaging, Bankers MAG., Winter 1971, at 47 .

100 There is evidence that this is occurring in conjunction with the holding company movement. The American Banker, for example, notes a 10.8 percent rise in interbank balances for their 702 sample banks outside New York Gity, between the end of 
for customers to stay with a particular supplier of the whole package so as to assure first call on those services, such as overlines, that are difficult to get during times of scarcity. Moreover, since nonbank suppliers are paid on a fee basis, country banks would hesitate to split off their purchase of nonfinancial services from city correspondents and thereby lose the full benefit-sometimes in terms of free services ${ }^{101}$ - of their interbank deposits. "Overall," observers have discovered, country banks are "more interested in the total relationship than in the price of a specific service." ${ }^{102}$ Any possibility of nonbank suppliers overcoming these built-in barriers to competition is likely to be conclusively foreclosed upon a merger.

As banks continue to expand into new service fields and enhance their capacities to supply a full package of services, nonbank suppliers could be confronted with a form of collective market foreclosure. The consequent entry disadvantages suffered by newcomers have been recognized by the Supreme Court in the Standard Oil Co. v. United States, ${ }^{103}$ decision, in which the cumulative effect of the use of similar exclusive dealing arrangements by seven oil companies controlling sixty-five percent of the market was condemned for permitting "the established suppliers individually to maintain their own standing and at the same time collectively, even though not collusively, to prevent a late arrival from wresting away more than an insignificant portion of the market."104

\section{ANTITRUST IMPLICATIONS}

\section{A. Market Crossover}

Crossing market power into new markets and thereby gaining advantages unrelated to merit or efficiencies is condemned as

September 1971 and the end of June 1972. Business gains during the period were a major factor. But, according to the American Banker, "[i]ncreased correspondent balances (outside New York City) have also resulted from the proliferation of bank holding companies during the period. The holding company's ability to engage in activities closed to banks enables its banking affiliates to offer a wider range of services, encouraging sharper growth in interbank balances of these banks." AM. BANKER, Dec. 18, 1972, at 8, col. 3.

${ }_{101}$ Nadler concludes that country banks favor interbank deposits rather than fees because "if a fee system were established, they would have to maintain fully compensatory fees. While now, with a balance system, the balances are negotiable and often can be well below the amount that would be necessary to compensate the correspondent fully for services rendered." Nadler, supra note 30, at 55; Knight, pt. III, supra note 40, at 15.

${ }^{102}$ Linneman \& Meinster, $A$ Major Strain in Correspondent Relations, Banking, Sept. 1970 , at 50 .

${ }_{103} 337$ U.S. 293 (1949).

${ }^{104}$ Id. at 309. See FTC v. Motion Picture Advertising Serv. Co., 344 U.S. 392, 395 (1953); Kessler \& Stern, Competition, Contract, and Vertical Integration, 69 YALE L.J. 1, 30 (1959). See also J. Dirlam \& A. KAHN, supra note 65, at 100-01. 
one of the more egregious consequences of vertical integration. ${ }^{105}$ It is particularly dangerous when the source of power is either a legally protected or well-ensconced monopoly. ${ }^{106}$ Primarily because of the leverage potential associated with the credit-extending power, banking is recognized as a fertile source of crossover. ${ }^{107}$ Protection under the antitrust laws against adverse crossover effects can be achieved by prohibiting certain forms of conduct or implementing structural remedies.

Through the Bank Holding Company Act Amendments of $1970,{ }^{108}$ Congress stressed the necessity of a restrictive structural policy to control the extent to which banks could cross over into the "commercial" sector. Acknowledging, however, that there were also justifications for crossover in some "commercial" activities, Congress conceded that banks should be permitted to enter those areas "so closely related to banking or managing or controlling banks as to be a proper incident thereto . . .."109 Anticipating increased bank entry into "closely related" fields, ${ }^{110}$ Congress endeavored to seal off any concomitant adverse cross-

105 J. Dirlam \& A. KAHN, supra note 65, at 143; C. KAYSEN \& D. 'luRner, supra note 48 , at 121 .

${ }^{106}$ United States v. Loew's, Inc., 371 U.S. 38 (1962); United States v. Griffith, 334 U.S. 100 (1948); International Salt Co. v. United States, 332 U.S. 392 (1947); C. KAYSEN $\&$ D. Turner, supra note 48 , at 121 ; see G. Hale \& R. HAle, Market Power: Size and SHAPE Under THE SHerman ACT 278-80 (1958).

${ }^{107}$ This is one of the factors leading Congress to enact laws curtailing unrestricted entry into commercial sectors. For restrictions on banks, see Act of June 16, 1933, ch. 89, 48 Stat. 162 (codified in scattered sections of 12 U.S.C.) (prohibiting. Federal Reserve member banks from engaging in the securities business and from holding for their own use stock of nonbanking institutions); The Bank Holding Company Act of 1956, ch. 240, 70 Stat. 133-39, as amended, 12 U.S.C. $\$ \$ 1841-50,1971-78$ (1970). See Recent Developments, The Antitrust Lawes and One-Bank Holding Companies: Breaking into the Piggy Bank, 1 CATHOlic U.L. Rev. 524 (1969).

108 Act of Dec. 31, 1970, Pub. L. No. 91-607, 84 Stat. 1760, 12 U.S.C. §§ 1841-50, $1971-78$ (1970).

${ }_{109}$ Id. § $103(4), 84$ Stat. 1764,12 U.S.C. § 1843(c)(8) (1970).

110 Thus far the Federal Reserve Board has listed eleven "closely related" activities:

(1) Lending, such as done by a mortgage, finance, credit card, or factoring company; (2) Operating consumer loan banks, industrial banks, Morris Plan banks, or industrial loan companies in accordance with state law; (3) Servicing loans or other extensions of credit for any person; (4) Performing trust functions; (5) Acting as investment or financial adviser; (6) Leasing personal property so long as the lease is expected to provide a full payout; (7) Making either equity or debt investments designed primarily to promote community welfare, such as development of low-income areas; (8) Providing bookkeeping or dataprocessing services for the internal operations of a holding company and its subsidiaries, and other data processing of a financial, banking, or related nature; (9) Acting as insurance agent or broker in offices at which the holding company or its subsidiaries are otherwise engaged in business, or in an adjacent office; (10) Managing property held by the bank holding company or its subsidiaries, for conducting its own bank and related operations, or property held in a fiduciary capacity; (11) Underwriting certain credit life, health, and accident insurance.

Blaine, Opportunities and Limitations for Expanding into Bank Holding Companies, 90 Banking L. J. 290, 300 (1973). 
over effects by attaching a conduct prohibition in the form of a per se antitying provision. Section 106 prohibits a bank from extending credit, leasing or selling property, furnishing any service, or fixing or varying the consideration for any of the foregoing on "condition or requirement . . . that the customer ... obtain some additional credit, property, or service from such bank [or from a bank holding company] other than a loan, discount, deposit, or trust service."111

Correspondent banking falls within the coverage of section $106 .^{112}$ For example, the provision could reach the use of float ${ }^{113}$ as a price concession (varying the consideration to sell other services), tying services to overline loans (credit), or using check clearing services as a lever to sell other services. Whether as a practical matter section 106 provides adequate protection against crossover-particularly when the market power advantage favors the city bank-depends upon how the provision is interpreted by the courts. One possible interpretation that would render section 106 impotent in certain situations is to read the "condition or requirement" language as restricting the reach of the provision to a prohibition of compulsory tie-ins. ${ }^{114}$

Correspondent banking is essentially a loose, informal and voluntary arrangement. ${ }^{115}$ It is not necessarily the pressure of compulsion that ties the service package together, but rather the convenience of dealing with a single supplier capable of satisfying all needs. Another strong but subtle factor cementing the relationship is the pull of personal contacts and a community of interest. Country banks are also guided by the unitary method of barter payment which produces a bigger return when interbank deposits are concentrated in one source in exchange for as extensive a blend of services as possible. ${ }^{116}$ Indeed, overt exertion of bargaining power appears to be foreign to correspondent banking. "Personal relationships," Knight notes, "often determine where balances would go and in time a degree of perma-

11 Act of Dec. 31, 1970, Pub. L. No. 91-607, § 106(b), 84 Stat. 1764, 12 U.S.C. $\S 1972$ (Supp. 1973).

112 "[T] he language is not intended to affect bank correspondent relationships, but insures that traditional correspondent relationships cannot be perverted by being tied to or conditioned upon maintenance or establishment of relationships with non-bank subsidiaries of bank holding companies, or with businesses operated within the bank or by the people controlling a bank." S. REP. No. 1094, 91st Cong., 2d Sess. 17 (1970).

113 For a discussion of "Aloat," see note 69 supra.

114 Note, The Bank Holding Company Act Amendments of 1970, 39 Geo. WaSH. L. Rev. 1200,1227 (1971).

$115 \mathrm{It}$ is also a permanent relationship. "There has to be something drastically wrong before a bank will make a change." City Banks Lure Country Dollars, BUS. WEEK, Oct. 24, 1959 , at $46,50-51$.

${ }_{116}$ See notes 75-76, 101 supra \& accompanying text. 
nence tended to solidify the relationship." 117 Hence, it could be argued that under the prevailing noncompulsory style of correspondent relationship and absent atypical conduct, section 106 is not applicable.

Section 106 is also subject to the interpretation that "condition or requirement" may be implied from the mere presence, albeit unexercised, of market power. ${ }^{118}$ The underlying assumption is that the buyer's awareness of his vulnerable position triggers acquiescence to the tie-in just as if he had been subjected to overt coercion. This view is compatible with the clear congressional purpose to erect a strict per se rule that would preclude crossover effects by making section 106 operative without proof of anticompetitive effects of market leverage over the tying product and regardless of the amount of commerce involved. ${ }^{119}$

Case law under traditional tie-in doctrine (which is not preempted by section 106) ${ }^{120}$ would afford relief only where conditions enable city banks to implement such arrangements through exercise of market leverage. This conclusion is derived from the current interpretation of section 1 of the Sherman Act, ${ }^{121}$ which holds that a prohibited tie-in exists only if the seller has some degree of market power over the tying product. ${ }^{122}$ Courts recognize that the exploitation of sufficient economic power over a tying product can be hidden in subtle pressures and complicated negotiations. By piercing the neutral outer layers of the relationship so as to get at telltale indicia of tacit tie-ins, courts subscribe to a functionally oriented approach. The buyers' special dependence on the arrangement, ${ }^{123}$ ingenious forms of refusal to deal, ${ }^{124}$ and disguising informal arrangements in onerous terms, ${ }^{125}$ have been found to reflect the use of market power.

118 Knight, pt. III, supra note 40 , at 3 .

${ }^{118}$ Naegele, Are All Bank Tie-Ins Illegal?, Bankers Mag., Summer 1971, at 46, 49; Reycraft, Antitrust Problems in Banking-1971, 16 AnTitrust Bull. 817, 852 (1971).

${ }_{119}$ Section 106 differs from traditional tie-in standards in that it constitutes an "absolute" per se prohibition. S. REP. No. 1094, 91st Cong., 2d Sess. 45 (1970) (supplementary views of Senator Brooke).

${ }_{120} 12$ U.S.C. \& 1978 (Supp. 1973).

12115 U.S.C. $\S 1$ (1970). Section 1 of the Sherman Act would be exclusively applicable because $\S 3$ of the Clayton Act does not apply to services. Thus, the Clayton. Act only makes it unlawful to lease or sell goods, wares, merchandise, machinery, supplies, or other commodities "on the condition, agreement or understanding that the lessee or purchaser... shall not use or deal in the goods ... of a competitor ..." 15 U.S.C. $\$ 14$ (1970). Credit has been held not to be within the purview of $\S 3$ of the Clayton Act. United States v. Investors Diversified Services, Inc., 102 F. Supp. 645 (D. Minn. 1951).

122 Fortner Enterprises v. United States Steel Corp., 394 U.S. 495 (1969); Turner,

The Validity of Tying Arrangements under the Antitrust Laws, 72 HARV. L. REv. 50, 61 (1958).

${ }_{123}$ United States v. General Dynamics Corp., 258 F. Supp. 36 (S.D.N.Y. 1966).

124 Osborne v. Sinclair Refining Co., 286 F.2d 832 (4th Cir. 1960).

125 United States v. Richfield Oil Corp., 99 F. Supp. 280 (S.D. Cal. 1951). 
Nonbank suppliers of competing services are most vulnerable to crossover effects when city correspondents deal with country banks from a position of market power. ${ }^{126}$ If, for example, one or more of the service components offered by city banks is in short supply, they can exploit the scarcity factor by requiring correspondent customers either to increase use of other services or to take on new services that nonbank firms may be presently supplying. During the period when market leverage is evenly balanced, or tilted toward the country bank, the only obstacles facing nonbank suppliers are the pull of intrabank affinities and the convenience of purchasing under a unitary pricing system. But as banks continue to perfect techniques for ascertaining the costs and value of interbank deposits, ${ }^{127}$ these affinities will more than likely break down in the face of an increasing tendency to compare prices and to shop around for the best deal. ${ }^{128}$

The extent to which section 106 can contain market crossover remains to be refined by the experience of case law. ${ }^{129}$ Both section 106 and traditional tie-in standards are likely to achieve most effective results when market leverage tilts toward the city correspondents. ${ }^{130}$ The possible extent of protection during these periods is yet unknown. Even under the most expansive interpretations, the best that conduct prohibitions can achieve is to preserve an opportunity for nonbank firms to gain access to the country bank market. Since vertical integration by merger would forever seal off this opportunity, the scope of the structural response has a critical bearing on the crossover issue.

126 See notes 73-79 supra \& accompanying text.

127 See Knight, pt. III, supra note 40.

${ }^{128}$ Recent changes by the Federal Reserve designed to speed up check collection will also result in greater emphasis on the fee system. "Small banks who thought that the use of deposit balances arising from float provided costless correspondent arrangements will reevaluate the cost of maintaining old relationships. The larger correspondent banks will be called upon to prove the merits of their performance under increasingly competitive conditions." The Road to Instant Banking, BaNk Srock Q., Nov. 1972, at 12, 13.

129 The only authority to date is unenlightening. In Clark v. United Bank of Denver Nat'l Ass'n., 5 TRade Reg. ReP. (1973 Trade Cas.) 974,514 (10th Cir. May 22, 1973), plaintiffs, prospective purchasers of a bank, sought financing from the defendant bank. After negotiations fell through, plaintiffs alleged that they had been required to promise orally to maintain an interest-free deposit of $\$ 1.5$ million in defendant's bank and that this constituted a tie-in violative of $\$ 106$. In affirming summary judgment for the defendants, the Court held that plaintiffs failed to demonstrate the existence of market power over the tying product, and that "[t]he legislative history ... indicates that the provision was not intended to interfere with the conduct of appropriate traditional banking practices. Included in these excepted banking practices was the maintenance of traditional correspondent relationships." Id. at 94,303.

Congress did not intend to immunize correspondent banking tie-ins. See note 112 supra. On the other hand, what is involved is a form of compensating balance arrangement: credit purportedly exchanged for maintaining a compensating balance deposit in defendant's bank. Congress did intend to exclude compensating balance arrangements from the reach of $\S 106$, Austin \& Solomon, supra note 71, at 18.

${ }_{130}$ This may presently not be the case. See notes $81-82$ supra \& accompanying text. 


\section{B. Vertical Integration by Merger}

The feasibility of a structural attack depends upon the resolution of two issues. One issue is quantitative and concerns the ability to obtain and accurately translate data into findings on the magnitude of competitive effects. The second issue is qualitative and involves resolution of the policy issue of the appropriateness of applying the usual antitrust standards to vertical correspondent bank mergers. Both of these issues are raised -but not resolved-in United States w. First National Bancorporation, Inc. ${ }^{131}$

In 1970, First National Bancorporation, Inc., sought to acquire First National Bank of Greeley (F.N.B. Greeley). With total deposits of over $\$ 495$ million, which constituted $12.9 \%$ of the statewide market, Bancorporation is the second largest of the seven registered bank holding companies in Colorado, a unit banking state. ${ }^{132}$ Its lead bank, First National Bank of Denver (F.N.B. Denver), was the largest commercial bank in both Colorado and the County of Denver with total deposits of $\$ 468$ million, which comprised $12.3 \%$ of the statewide market and $25.3 \%$ of the Denver market. Denver, the population, banking and commercial center of Colorado, is likewise that state's correspondent banking center, with First National of Denver the largest of six suppliers of correspondent banking services. ${ }^{133}$

Located around fifty miles from Denver, F.N.B. Greeley had total deposits of slightly over $\$ 39$ million, giving it $31.8 \%$ of the Greeley area market and making it the fifteenth largest commercial bank in the state. The Greeley area was serviced by eight banks, including F.N.B. Greeley, of which five were affiliated with registered holding companies. Affiliated Bankshares controlled three banks with a total market share of $40.2 \%$, including Greeley National whose market share was the same as that of F.N.B. Greeley. United Bank controlled two banks, with market shares of $20 \%$ and $1.7 \%$, and the two nonaffiliated banks controlled, respectively, $2.2 \%$ and $4 \%$ of the market.

The government's original complaint charged that the acquisition of F.N.B. Greeley by Bancorporation would have an

131329 F. Supp. 1003 (D. Colo. 1971). The statistical description of the facts surrounding the Bancorporation-F.N.B. Greeley acquisition is taken from the opinion.

${ }^{132}$ Under unit banking, branching is prohibited. Thus a unit bank operates only a single banking office. L. Chandler, supra note 46, at 399. See G. Fischer, Bank Holding COMPANIES 1-4 (1961).

${ }_{133}$ According to figures offered by the Government, F.N.B. Denver had around $37 \%$ of the Colorado interbank deposits held by the 6 Denver correspondent banks, while the next 2 banks each held around $23 \%$. Brief for Appellant at 6-7, United States v. First Nat'l Bancorporation, Inc., 410 U.S. 577 (1973). 
adverse affect on the Greeley area market by eliminating Bancorporation as a potential competitor. ${ }^{134}$ Later the complaint was amended to include a two-pronged vertical integration argument alleging that rival city correspondent suppliers in competition with First National of Denver would be foreclosed from the F.N.B. Greeley account, and also that if it were approved, the proposed acquisition would trigger other defensive acquisitions, ${ }^{135}$ as it was itself triggered by previous vertical mergers.

Emphasizing the absence of "judicial recognition"136 of the plaintiff's vertical integration theory, the district court dealt cautiously with the relevant product and geographic market contentions. It reached no conclusion on these issues, and it held against the Government on the allegation of adverse competitive effects.

\section{Relevant Markets}

\section{a. The Product Market}

Impeded in many situations by unsatisfactory measuring techniques, lacunae in economic data and adversarial efforts at tailoring what data do exist, smooth relerant market analysis is rarely possible in antitrust litigation. To cope with these obstacles, courts have developed a flexible set of standards. Under a mandate to establish product boundaries according to where "in fact, competition exists," 137 discretion exists to find broad markets determined by the reasonable interchangeability of use or cross-elasticity of demand for products, or to carve out submarkets under the guidance of practical indicia. Practical indicia include "recognition of the submarket as a separate economic entity, the product's peculiar characteristics and uses, unique production facilities, distinct customers, distinct prices, sensitivity to price changes and specialized vendors." 138

In United States $v$. First National Bancorporation, Inc., the district court sifted the service components of the correspondent banking barter through the standard tests with inconclusive

${ }^{134}$ The Government argued that entry should be channeled into acquisition of Greeley State Bank, "a very small institution," or through de novo entry. 329 F. Supp. at 1010.

${ }^{135}$ See Plaintiff's Pre-Trial Proposed Findings of Fact and Conclusions of Law at 43-49, United States v. First Nat'l Bancorporation, Inc., 329 F. Supp. 1003 (D. Colo. 1971).

136329 F. Supp. at 1016.

${ }^{137}$ Brown Shoe Co. v. United States, 370 U.S. 294, 326 (1962).

${ }^{138}$ Id. at 325. 
results. Evidence of "some recognition"139 within the banking community of the service package as a discrete "economic activity," 140 and testimony concerning the employment of unique production facilities in servicing accounts and the involvement of distinct customers and specialized vendors, were both seemingly outweighed by the lack of uniformity among the service packages. Summarizing, the court said: "At best, the group of services offered varies from bank to bank and the common elements are the demand deposit and the overline loan."141

Determination of the relevant product market in correspondent banking involves consideration of two issues. The first is whether the correspondent bank service package is a discrete product market within the broader field of commercial banking. The second is whether services furnished by nonbank suppliers are in competition with the offerings of correspondents and thus includible in the relevant market. The first issue was discussed with equivocation; the second, although raised by the defendants, ${ }^{142}$ was ignored by the court.

The line of analysis employed in avoiding the first question, the discreteness of the service package within commercial banking, appears to be unsupportable under the general standards. For one thing, it is not necessary that the full gamut of tests be satisfied. Supplying "no precise formula for judgment," ${ }^{143}$ the "practical indicia" are intended to serve as guides, not absolutes. ${ }^{144}$ Moreover, a mass of literature descriptive of correspondent banking suggests that most of the standards are, in varying degrees, satisfied. The longstanding industry recognition of correspondent banking as a completely distinct part of the banking process is hardly open to question. ${ }^{145}$ There is clear

\footnotetext{
139329 F. Supp. at 1017.

${ }^{140} \mathrm{Id}$.

${ }^{141} I d$.

142 The defendants argued that

correspondent services more likely appear to be a method whereby a "country"

bank and a "city" bank enter into an agency or conduit relationship for

funneling the services of various departments of the "city" bank to the ultimate customer of the "country" bank. In any event, there is no evidence to indicate that there is anything unique about any of the services offered to correspondents which would thereby immunize all of the other items of services to correspondents from competition and thus to conclude a "cluster" or "congeries" of service to a correspondent is a relevant product.
}

Defendants' Post Trial Proposed Findings of Fact and Conclusions of Law at 28, United States v. First Nat'l Bancorporation, Inc., 329 F. Supp. 1003 (D. Colo. 1971). The defendants argued that services such as pension and profit-sharing plans and data processing are supplied by nonbank firms in competition with city banks. Id. at 33 .

${ }_{143}$ United States v. Continental Can Co., 378 U.S. 441, 449 (1964).

144 In Reynolds Metals Co. v. FTC, 309 F.2d 223 (D.C. Cir. 1962), the court found a relevant market where 2 of 3 standards were satisfied. Id. at 228.

${ }_{145}$ See notes 10-35 supra \& accompanying text. The American Bankers Association 
acknowledgment that, as a submarket within banking, it involves the interplay of specialized vendors (large urban institutions), distinct customers (medium or small country banks) and unique production facilities (check clearing, specialized departments and personnel committed to handling the correspondent accounts).

The second issue, the appropriateness of establishing an even narrower submarket by not including in the product universe those services supplied by nonbanking firms, can be resolved by reference to the cluster doctrine. In United States $v$. Philadelphia National Bank, ${ }^{146}$ the Supreme Court clustered the diverse services provided by commercial banks into a single product market, reasoning that some of the services involved were unique to banking while those that face competition from nonbank suppliers enjoyed the advantages of consumer preference. ${ }^{147}$ The logic of clustering was subsequently confirmed in United States v. Grinnell Corp.; ${ }^{148}$ there the Supreme Court emphasized that "where that combination reflects commercial realities," 149 it is appropriate to combine in a single market a number of different services.

Commercial realities which confirm the guidelines of Philadelphia National Bank indicate that the correspondent service package is a distinct cluster, since the impact of nonbank suppliers of services is too limited to justify their inclusion in the market. Specialty firms supplying services like data processing and investment advice do not compete over the full range of services offered by correspondent banks. Some services, such as check clearing, are the exclusive sphere of banking. Likewise, banks are uniquely suited to furnish specialized services such as advice on training personnel, ${ }^{150}$ technical know-how on lending or short-term investment operations, ${ }^{151}$ or as F.N.B. Denver offered, a personnel placement service to fill vacancies in country banks. ${ }^{152}$ There is a consumer preference factor in that country banks find it economically convenient to satisfy all needs from a single source. This effect is further reinforced by the unitary method of interbank deposit payments which tends to encourage the country bank to get as wide a range of services as possible in

recently created a committee "to deal with the specialized problems of correspondent banking. . ."Banking, Nov. 1971, at 19.

146374 U.S. 321 (1963).

147 Id. at 356 .

148384 U.S. 563 (1966).

$149 \mathrm{Id}$. at 572 .

150 See note 18 supra.

151 See note 16 supra.

152 Plaintiffs Pre-Trial Proposed Findings of Fact and Conclusions of Law at 16,

United States v. First Nat'l Bancorporation, Inc., 329 F. Supp. 1003 (D. Colo. 1971). 
exchange for its deposits. ${ }^{153}$ Hence, while country banks may split purchases among banking and nonbanking sources, the practicalities are on the side of clustering the purchase of all service needs at a single banking source. ${ }^{154}$

A most important point not discussed in First National Bancorporation is that relevant product market analysis must take into consideration the ramifications of the barter factor. Any argument that a city correspondent-country bank merger will have an adverse effect on competition in the city bank market raises two interrelated possibilities-first, city rivals will lose the newly acquired country bank as a customer for services, and second, they will likewise be cut off from a source of raw materials-interbank deposits. While the anticompetitive effects are double edged, the degree of impact would depend upon the shifts of market leverage. Adverse effects would be greatest on the interbank deposit side when credit is tight and deposit raw materials are scarce; or, depending upon the service component offered, the impact would possibly shift to the service side in times of credit easing. ${ }^{155}$ Since the allegation is likely to be that the merger raises a probability of harmful effects derived from either component of the barter, a finely drawn relevant product market for the service package, especially when the effects are strongest as to interbank deposits, should not be necessary.

\section{b. The Geographic Market}

In First National Bancorporation the Government endeavored to establish Colorado as the relevant geographic market. The court pointed to "some evidence" that Colorado correspondent banks solicit correspondent business over state lines, citing figures that showed that thirty to forty percent of F.N.B. Denver's interbank deposits came from out of state. ${ }^{156}$ At the same time it was acknowledged that the "[p]laintiff may have a valid argument in asserting that only Colorado banks can utilize their Denver correspondent as a depository for bonds or other collateral which are required by Colorado law to be posted as security for deposits of the State Treasurer in Colorado

${ }^{1.53}$ One persuasive reason for this is that country banks feel they get "free" services. See note 101 supra \& accompanying text.

${ }_{154}$ But recent Federal Reserve regulatory changes are likely to dilute the tendency to cluster purchases from a single source. See note 128 supra \& accompanying text; Roundtable, supra note 75 , at 19 .

${ }^{155}$ See notes 80-82 supra \& accompanying text.

${ }^{156}$ The Court noted that $69 \%$ of F.N.B. Denver's interbank deposits came from 122 Colorado banks. The remaining deposits came from Montana, Wyoming, Nebraska, Kansas, Utah, Idaho, New Mexico, Arizona and Texas. 329 F. Supp. at 1018. 
banks." 157 The Government's contention that only Denver correspondent banks had the expertise to supply advice on matters peculiar to Colorado law was mentioned without additional comment. Consistent with the handling of the relevant product issue, no conclusion was reached on the merits of the Government's argument.

The distant neutrality of the court on the geographic market issue furnishes immunity to critical evaluation. It does, nevertheless, serve as a preface for a survey of some of the pertinent characteristics of correspondent banking which would have to be meshed with established guidelines in order to satisfactorily deal with this issue.

The Supreme Court has stated that a relevant geographic market must be consistent with the area where the competitive effects will be direct and have the greatest, but not necessarily an exclusive, impact. ${ }^{158}$ Reference is to be made to the seller's sphere of operations and the reach of the customer's supply alternatives. ${ }^{159}$ Supporting this set of directions is the responsibility to recognize and measure the significance of potential competition and conditions of entry. ${ }^{160}$

As a general proposition, the relevant geographic market will be determined by the interplay of geographic and economic proximity between city and country banks. The location of city correspondents is set according to the anticipated drain on resource capabilities. They are of medium to large size, and in order to properly fulfill full service correspondent (as contrasted with merely clearing) functions, must be situated in centers of economic activity. Generally, the closer the geographic proximity between an economic center and country bank markets, the less the necessity to establish other correspondent ties in other centers. ${ }^{161}$

Economic proximity, which is not necessarily consistent with the geographical spread, is determined by the interplay of such

157 Id.

${ }^{158}$ In United States v. Philadelphia Nat'l Bank, 374 U.S. 321 (1963), the Supreme Court recommended use of a "workable compromise": "some fair intermediate delineation which avoids the indefensible extremes of drawing the market either so expansively as to make the effect of the merger upon competition seem insignificant, because only the very largest bank customers are taken into account in defining the market, or so narrowly as to place appellees in different markets, because only the smallest customers are considered." Id. at 361 .

The most relaxed test appears in United States v. Pabst Brewing Co., 384 U.S. 546 (1966), in which the Supreme Court denied the need to delineate the relevant geographic market "by metes and bounds as a surveyor would lay off a plot of ground." Id. at 549.

159 Tampa Elec. Co. v. Nashville Coal Co., 365 U.S. 320 (1961).

160 United States v. Pabst Brewing Co., 384 U.S. 546, 556-57 (1969) (Harlan, J., concurring).

${ }^{161}$ See Lawrence \& Lougee, supra note 35, at 361-62. 
factors as the range of technical expertise offered, special area needs, the size of the country bank and entry barriers created by state laws. For primary sources of supplies, country banks are likely to stay close to home and work through banks who understand the often risky and technical needs of their customers. In addition, they must maintain correspondent connections in markets where check clearing for customers tends to be heavy. Larger country banks are likely to require more numerous and extended correspondent relationships. ${ }^{162}$ Moreover, special needs, such as farm financing, could bind institutions to nearby city banks offering regionally oriented programs. Finally, the point made by the government that barriers to entry created by state laws can operate to delineate a geographic market is salient. For example, special state laws, such as those relating to state reserve requirements, may make it necessary to deal with instate correspondents. Likewise the complexity of certain types of statutes, for instance, state taxation laws, requires instate legal and financial expertise.

\section{Competitive Effects}

In holding against the Government on the merits of the vertical integration allegation, the court in First National Bancorporation indicated a lack of satisfaction with the methods suggested for measuring market foreclosure. The court further held that even assuming the accuracy of either proposed method of quantification, market foreclosure would have been too insignificant to be held violative of the Clayton Act.

\section{a. Quantification of Market Foreclosure}

Payment for correspondent banking services is made by interbank deposits, while revenue is determined by reference to costs as shown by individual account analysis. ${ }^{163}$ To measure foreclosure the Government relied on interbank deposits as reflected on the individual bank balance sheet and published call report data. As a statistical measure, interbank deposits are inconclusive as to uncollected balances which have been deposited with the reporting bank but not yet collected. ${ }^{164}$ Moreover,

${ }^{162}$ Knight, pt. 1 , supra note 12 , at 9 .

${ }^{163}$ See Knight, pt. III, supra note 40.

164 This is float and can constitute an interest-free loan to the depositing country bank, provided withdrawal is permitted by the city correspondent prior to collection from the drawee bank. The drawee bank, of course, has full use of these "on us" uncollected checks, and speeded-up check collection systems tend to result in loss of investment funds by outlying country banks from which check collections have been most delayed in the past. See note 69 supra \& accompanying text; Knight, pt. III, supra note 40 , at 4. 
interbank deposits may include some part of the legal reserve requirements, which modern account analysis tends also to deduct in establishing earnings allowance on the account for the country correspondent. Similarly, the overall interbank deposit universe against which the individual bank's share of correspondent business is measured includes any remaining float within the banking market and reserve requirements held in the form of interbank deposits. ${ }^{165}$

The defendants argued that the presence of float substantially overstated the amount of correspondent business "usurped" by the merger and thus net income furnished a more accurate measuring formula. ${ }^{166}$ The court, without expressly agreeing with this contention, noted that F.N.B. Denver determines the profitability of the larger accounts by ascertaining the income produced by the average balance. ${ }^{167}$ The average balance is calculated by deducting from the individual country bank's deposits: the then seventeen and one-half percent reserve requirement, float, and whatever expenses are chargeable against the account.

The methods presented to the court suffer from statistical defects. Until a money-fee pricing method is adopted, calculations of individual market shares and the market universe will be vulnerable to distortions of over or underpayments. Neither method accounts for failures to charge fully, or at all, for some services. ${ }^{168}$ Nor do they reveal those instances where city correspondents fail to make adequate refunds for overpayments. Likewise, neither method comprehends the situation in which services, such as computer time, are paid for by a money fee. ${ }^{169}$

Without endeavoring to sort out the ramifications of these defects, the court rejected both methods. The use of gross interbank deposits was eschewed with the cryptic comment that "banks themselves use a much more sophisticated and accurate 64 (1972).

${ }_{166}$ Account analysis of the F.N.B. Greeley account with F.N.B. Denver in 1970 showed a net operating profit of $\$ 5,000$ (or $\$ 2,500$ after taxes) ... Net income of Bancorporation after taxes was $\$ 5.4$ million (Moody's Bank \& Finance Directory, 1971). Thus the contribution of the F.N.B. Greeley account to the profitability of Bancorporation was five one-hundredths of one percent. The profit "foreclosure" among the "Denver Six" was one one-hundredths of one per cent.

Brief for Appellees at 90, United States v. First Nat'l Bancorporation, Inc., 410 U.S. 577 (1973).

${ }_{167} 329$ F. Supp. at 1019.

${ }^{168}$ Some common examples of activities that may not be included in analysis statements are: security safekeeping and investment advice, overline loan participations, assistance with sophisticated types of loans, account referrals, credit information and loan lines. Knight, pt. III, supra note 40 , at 7 . i69 Id. 15. 
method ...."170 Account analysis, the "more sophisticated" method, was deemed unsatisfactory because variations in the amount of float from customer to customer rendered a bank's gross average interbank deposits "at best a very rough, inaccurate approximation ... of correspondent banking business ...."."171

The court's assumption that interbank deposits as a measure of foreclosure compares unfavorably with account analysis is perhaps attributable to a failure to recognize that the statistical problems of the latter technique are likely to pose the more serious problem. Account analysis is in the first stage of development; it has been said that it is "even less sophisticated than general accounting." 172 Inherent in account analysis is a lack of industry-wide standardization in methods of compilation. On an internal basis, valuation of each of the service components is, as one specialist notes, "difficult, not to say impossible ...."173 Accounting systems are likely to vary from bank to bank. Classification and allocation of costs depend on individual bank inclination and, thus, vary from bank to bank. ${ }^{174}$ Under these conditions, it is doubtful whether a reasonably accurate market universe could be constructed for purposes of ascertaining a bank's share of the market. This formidable problem is demonstrated by the fact that there exist no data on industrywide profits based on account analysis. In the absence of such information, comparisons which would reveal a particular bank's share of the industry's profits are, of course, precluded. ${ }^{175}$

70.

170329 F. Supp. at 1019.

171 Id.

172 How to Compensate Correspondents?, Banking, March 1973, at 60.

${ }^{173}$ Carr, Pricing, Correspondent Banking Services, B ANKERS MAG., Summer 1967, at 65,

${ }^{174}$ The methods of account analysis differ widely among banks. Some correspondents charge for services such as safekeeping of securities, wire transfers, currency and coin preparation, advice, etc., while others do not figure these items directly in the analysis. Virtually all banks, however, levy fees for ledger entries, deposited items, and returned items. Unfortunately, there is little agreement among the larger banks about the charges which should be made for providing even the most basic services. In part, these differences are due to alternative methods of allocating and calculating cost. Three basic approaches may be followed: marginal cost pricing, average variable cost pricing, and average total cost pricing.

Knight, pt. III, supra note 40, at 4-5 (emphasis added); See How to Compensate Correspondents, supra note 172 , at 65.

${ }_{175}$ The closest to a profits concept would be shown by the Federal Reserve Board in its annual analysis of member bank income. Operating income is set against operating expenses, including net securities gains and losses and extraordinary charges or credits after taxes, and a net income figure is derived. See Cagle, Member Bank Income, 1971, 58 FED. RESERVE Bull. 446, 448 (1972). See also FDIC, ANNUAL RePORT-1971, at 234 (Table 118) (1972); FDIC, BANK Operating Statistics-1971 (Table C, Income and Expenses of Insured Commercial Banks), (Table E, Selected Operating Ratios of Insured Commercial Banks, for States and Sub-sections of States). For a discussion of the 
Outright rejection of gross interbank deposits is also questionable. Although imperfect, this method nevertheless has the advantage of furnishing a reasonably accurate profile of the outer limits of the services-deposits barter. Lnlike profitability, which is essentially a reflection of the vicissitudes of accounting methodology and cost fluctuations, interbank deposits state fairly accurately the extent to which a country bank is channeling raw materials to its city correspondent. Moreover, a better grasp of the full potential of foreclosure in the barter can be obtained from information revealing the extent of each party's call upon the other. For example, interbank deposits state the base for foreclosure effects in those peripheral services priced by dollar fee since a large interbank deposit commitment by the country bank is likely to mean an equally large use of peripheral services. Finally, as to either method, it is important to note that antitrust law has never required pinpoint accuracy in economic evidence, but has instead recognized the practical necessity of working with data of varying shades of accuracy.

\section{Argument}

b. The Court's Evaluation of the Government's Vertical Merger

Positing interbank deposits to be an "acceptable measure of ... foreclosure," ${ }^{176}$ the court carved out two geographic markets and held that market foreclosure in each would be de minimis and therefore not illegal. For a five-state area where the major Denver banks did $90 \%$ of their correspondent business, the gain in F.N.B. Denver's business from the acquisition of F.N.B. Greeley's interbank deposits was set at $0.2 \%$. On the country bank side of the barter, acquisition of F.N.B Greeley's share of interbank deposits would foreclose somewhat less that $0.7 \%$ of the interbank deposits held by Colorado banks in all banks. ${ }^{177}$ The Government's market, limited to F.N.B. Greeley's interbank deposits measured against correspondent balances from all Colorado banks held by the six Denver city banks, resulted in $1.2 \%$ foreclosure. Although it rejected the appropriateness of the plaintiff's proposed area as a relevant market, the court in a

many complicated factors which go into determination of bank profits, see R. RoBinson, The Management of Bank Funds 388 (2d ed. 1962). The regulatory agencies and the Department consider net income comparisons in merger analysis as elements in comparative performance in different banking markets, but not as a measure of volume of business.

176329 F. Supp. at 1019 .

${ }^{177} I d$. 
footnote added: "This percentage, as well, appears to be insubstantial under the circumstances presented by this case." 178

Viewing the facts in First National Bancorporation as a "wholly different competitive situation" from one in which "nation-wide giant corporations [are] threatening to take over an entire line of commerce and divide it up between them," 179 the court indicated that where a local or regional banking market is involved, it is appropriate to require a higher degree of foreclosure. ${ }^{180}$ In addition, the Government's contention that it was necessary to consider the implications of a vertical integration trend was discounted on the ground that the acquisitions involved in the trend-"particularly as concerns Bancorporation's participation"181_were either pending before the Federal Reserve Board or in the process of litigation, thereby rendering any assumptions on a trend too speculative.

The proposition that different standards be applied when competitive disruptions are felt exclusively in local or regional markets is unsupported by both the cases and the policy. ${ }^{182}$ The Supreme Court has unequivocally repudiated such a view, most recently in United States v. Phillipsburg National Bank $\mathcal{E}^{3}$ Trust Co. ${ }^{183}$ where the argument that a merger of two small banks with total assets of $\$ 23.9$ and $\$ 17.3$ million and serving a population of 90,000 was not covered by section 7 of the Clayton Act because the market was not an "economically significant section of the country" was summarily dismissed. ${ }^{184}$ It is firmly estab-

${ }^{178} \mathrm{Id}$. at $1019 \mathrm{n} .13$.

${ }^{179}$ Id. at 1019 .

${ }^{180}$ In any event, a local or regional banking market presents a wholly different competitive situation from a national retail sales or supply market in shoes, chemicals, paper or steel. We are not here dealing with nation-wide giant corporatiōns threatening to take over an entire line of commerce and divide it up between them, and the measure of substantiality must be gauged in the context of the particular industry and market involved.

Id. at 1019-20. The court was undoubtedly responsive to the defendant's argument that the foreclosure cases relied upon by the Government involved both national and local markets and that the foreclosure in the local markets in these cases had been considerably higher than the $1.2 \%$ figure asserted by the plaintiff in Bancorporation. See Defendants' Post Trial Brief at 56-60, id. In each of these decisions, however, there was no indication of a separate standard for national and regional markets. Furthermore, the single finding on the extent of foreclosure was never deemed dispositive, but one of a number of factors to be evaluated.

181 Id. at 1020 .

182 Kintner \& Hansen, A Review of the Law of Bank Mergers, 14 B.C. IND. \& CoM. L. REv. 213, 246 (1972). ${ }_{183} 399$ U.S. 350,365 (1970).

184 The defendants had relied on language in Brown Shoe Co. v. United States, 370 U.S. 294, 320 (1962), stating that "[t]he deletion of the word 'community' in the original Act's description of the relevant geographic market is another illustration of Congress' desire to indicate that its concern was with the adverse effects of a given merger on competition only in an economically significant 'section' of the country." In Phillipsburg the Court responded:

In Brown Shoe, however, we found "relevant geographic markets" in cities "with 
lished that full antitrust protection is important in local or regional banking markets where small customers generally do not have the resources to choose among a wide range of options. ${ }^{185}$ Finally, to dilute standards by creating a different set of proscriptive tests for "regional violations" contradicts the Congressional directive that small businesses deserve the full protection of the antitrust laws. ${ }^{186}$

Because the degree of market foreclosure constitutes in most cases a readily obtainable and easily readable indicator of the extent to which an open and unfettered exchange process has been disturbed, it is considered the first point of reference for judgment of anticompetitive effects of vertical integration. ${ }^{187}$ The higher the level of foreclosure, the greater the chance that a court will conclude that firms have been denied "a fair opportunity to compete"188 on the merits of the products. The decisions support the conclusion that foreclosure of $0.2 \%$ and $0.7 \%$ is on the margin of, if not within, the de minimis classification. ${ }^{189}$

The decision in Brown Shoe Co. v. United States ${ }^{190}$ firmly established the principle that proscription does not hinge exclusively on the level of foreclosure; inquiry normally must be extended to consider the possibility of harmful structural permutations. ${ }^{191}$ In vertical integration the principal means of adversely affecting structure is through the spreading of market power from one horizontal market to another. ${ }^{192}$ This line of inquiry is relevant to correspondent banking where the statistics of foreclosure are particularly unreliable in exposing the full

a population exceeding 10,000 and their environs"... Phillipsburg-Easton and their immediate environs had a population of almost 90,000 in 1960 . Seven banks compete for their business. This market is clearly an economically significant section of the country for the purposes of $\S 7$.

399 U.S. at 365.

185 United States v. Phillipsburg Nat'l Bank, 399 U.S. 350 (1970). In that case the Court stated: "Mergers of directly competing small commercial banks in small communities, no less than those of large banks in large communities, are subject to scrutiny ... Id. at 358 .

186 Brown Shoe Co. v. United States, 370 U.S. 294, 333 (1962).

187 "The primary vice of a vertical merger or other arrangement tying a customer to a supplier is that, by foreclosing the competition of either party from a segment of the market otherwise open to them, the arrangement may act as a 'clog on competition' ...." Brown Shoe Co. v. United States, 370 U.S. 294, 323-24 (1962). See U.S. Dep't of Justice, Merger Guidelines, ANTTTRust Developments 1955-1968, app. A, If 3 (1968).

188370 U.S. at 324,328 .

${ }_{189}$ In United States v. Kimberly-Clark Corp., 264 F. Supp. 439, 462 (N.D. Cal. 1967), the court proscribed a vertical merger involving foreclosure of product lines of $2 \%, 1.8 \%$ and $2.7 \%$ (constituting an average market foreclosure of $2 \%$ ). On the other hand, in United States v. Standard Oil Co., 1964 Trade Cas. I 71,215 (N.D. Cal. 1964), it was held that market foreclosure of $0.1 \%$ was "de minimis by any standard."

190370 U.S. 294 (1962).

${ }^{191} I d$. at $328-30$. See United States v. Standard Oil Co., 1966 Trade Cas. If 71,736, at 82,355 (D.N.J. 1966).

192 P. AREedA, ANIITRusT ANalysis 521-22 (1967); C. KAYSEN \& D. TuRner, supra note 48 , at 121-23. 
potential for spreading market power. Percentages do not reveal the spreading derived from being able to get first priority access to the acquired country bank's deposits. The extent of the spreading effects would depend upon the condition of the credit market. Because the money supply is determined by external forces over which the industry has little control, the disadvantages to rivals from foreclosure-and the corresponding benefits to those having an assured access to deposits-may increase exponentially as the shortage increases. Likewise, foreclosure figures do not reveal the advantage of having a fixed inside track on getting those accounts that outgrow the capacity of the country bank. ${ }^{193}$ At the other end of the barter on the country bank side, foreclosure figures might understate the leveragespreading clout from having access to overlines in periods of limited credit $^{194}$ or having first, or exclusive, call on important services.

The court in First National Bancorporation focused primarily on the particular acquisitions of the defendant and ignored evidence of a statewide trend toward bank concentration. The court dismissed this evidence on the basis that the acquisitions involved in the trend-"particularly as concerns Bancorporation's participation"195_were either pending before the Federal Reserve Board or in the process of litigation, thereby rendering any assumption of a trend too speculative. In reaching this conclusion the court has again departed from prior decisions, in which the sanctity of a competitive market structure was deemed so critical that even where foreclosure was slight, an acquisition was prohibited where a "chain reaction" 196 to merger activity set in motion a trend of mergers. ${ }^{197}$ Thus, the merger at issue should be viewed within the context of all members of the industry, and attention should be directed towards the "trend toward concentration in the industry." 198 It is, moreover, the cumulative effect that is deemed to be significant. The acquisition of a small firm is condemnable if part of a series of successive mergers pointing to the likelihood of a concentrated market structure. ${ }^{199}$

${ }^{193}$ See text accompanying note 28 supra.

${ }^{194}$ See text accompanying note 73 supra.

195329 F. Supp. at 1019-20.

196 United States v. Kimberly-Clark Corp., 264 F. Supp. 439, 447 (N.D. Cal. 1967).

197 Brown Shoe Co. v. United States, 370 U.S. 294, 332-33 (1962); United States v. Von's Grocery Co., 384 U.S. 270,277 (1966).

198370 U.S. at 332 (emphasis added).

199370 U.S. at 345 n.72. "A fundamental purpose of amending $\$ 7$ was to arrest the trend toward concentration, the tendency to monopoly, before the consumer's alternatives disappeared through merger, and that purpose would be ill-served if the law stayed its 


\section{Policy Factors}

The facts and opinion in United States v. First National Bancorporation, Inc., expose many of the problems in relating antitrust principles to correspondent banking; the court, however, fails to devise any solutions. Equivocation on relevant markets, confusion over quantification, and a juggling of standards can probably be attributed to the difficulties of dealing on first impression with an unusually complicated practice. In the future, courts will have a better chance of overcoming some of these difficulties by relating correspondent banking to the policy interface of banking and antitrust.

Bank regulatory policy decrees departure from the norms of a freely competitive market in four major ways: entry into banking is at the discretion of regulatory bodies; branching mobility is often restricted by state law; formal and informal limits are imposed on pricing; and limits on the supply of some raw materials are set by monetary and fiscal policy. ${ }^{200}$ Adhering to Justice Brennan's admonition that the restrictive regulatory network over a critical industry like banking "makes the play of competition not less important but more so,"201 the Justice Department has developed a two-pronged policy schedule to contain those effects of regulation deemed incompatible with desirable competitive goals and susceptible of correction. The first prong involves the use of standard conduct prohibitions against restraints of trade such as price fixing. ${ }^{202}$ The second prong is to attack efforts to aggrandize through merger. Suits have been filed attacking horizontal mergers and market extension acquisitions by holding companies where a statewide pattern of concentration is emerging. ${ }^{203}$ The underlying rationale is that com-

hand until 10 , or 20 , or 30 more ... banks were absorbed." United States v. Philadelphia Nat'l Bank, 374 U.S. 321,367 (1963). See Darnell, Bank Holding Companies and Competition: The First National Bancorporation Case, 89 BANkING L.J. 291, 312-13 (1972).

It may be argued that the "triggering" and "trend" effects have less significance in a regulated industry, such as banking, because entry and approval for acquisition is at the discretion of the various regulatory agencies. The Justice Department has responded by contending that: "Regulators and regulatory policies change-and regulatory decisions involve a subjective element. Given this combination of factors, decisions should not turn on what a district judge, as a finder of fact, predicts a particular regulator might do." Bank Acquisitions in New Markets: A Whiff of Clorox and Garlic, Speech by Donald I. Baker, Antitrust Division, Department of Justice, in Detroit, Michigan, Sept. 24, 1970 [hereinafter cited as Bank Acquisitions in New Markets].

${ }^{200}$ See notes 55-57 supra \& accompanying text.

201374 U.S. at 372.

202 E.g., United States v. Northwestern Nat'l Bank, 1967 Trade Cas. If 71,020 (D. Minn. 1964) (price fixing).

${ }_{203}^{0 . g .}$., United States x. Phillipsburg Nat'l Bank, 399 U.S. 350 (1970); United States v. Philadelphia Nat'l Bank, 374 U.S. 321 (1963); United States v. Crocker-Anglo Nat'l Bank, 277 F. Supp. 133 (N.D. Cal. 1967); United States v. Marine Bancorporation, Inc., Civil No. 237-71C2 (W.D. Wash. Jan. 31, 1973), appeal docketed, No. 73-38 (U.S. June $30,1973)$. 
petition is best served by maintaining as many shopping options for the public as are consistent with present and future needs. ${ }^{204}$ Implicit in this policy is the preservation of small or mediumsized independent banks which provide the public with a shopping option attuned to local needs, ${ }^{205}$ while also serving as a possible future source of competition for large banks. ${ }^{206} \mathrm{~A}$ burden is placed on banks seeking to expand to do so in a procompetitive manner. ${ }^{207}$ This is implemented by attacking anticompetitive acquisitions where entry could be accomplished either by a "toehold" merger with a small, perhaps moribund bank, or by de novo entry. ${ }^{208}$ Entering the market in this manner, "the new entrant has every incentive to increase its market position-to do this with strong competitive efforts covering new services, lower prices, longer hours and all the rest."209

The antitrust principle that the market is best served by maintenance of numerous shopping options is in tune with a strong sentiment in banking that diversity in the form of a system of large, medium and small institutions constitutes the most beneficial means of responding to the needs of the public. ${ }^{210} \mathrm{~A}$ correspondent banking system unencumbered by deleterious vertical restraints is in tune with both of these policy strains. ${ }^{211}$

${ }^{204}$ This is also deemed to serve a social purpose: "It has long been recognized that one of the objectives of the Sherman Act was to preserve, for social rather than economic reasons, a high degree of independence, multiplicity, and variety in the economic system." Albrecht v. Herald Co., 390 U.S. 145, 158 (1968) (Harlan, J., dissenting).

${ }^{205}$ Protection of the small businessman from the erosion of banking alternatives was the dominant theme of United States v. Phillipsburg Nat'l Bank, 399 U.S. 350, 358 (1970).

${ }^{206}$ Baker, Potential Competition in Banking: After Greeley, What?, BNA ANTITrust \&

TRADE ReG. ReP., No. 606, Mar. 27, 1973, at D-4.

${ }^{207}$ Our approach is thus quite clear and simple. In a state (a metropolitan area) dominated by a few large banks, these banks should by virtue of their resources be regarded as the principal potential entrants into markets which they can legally enter. These are the institutions with the competitive muscle and they should be obliged to use it in a pro-competitive way.

Bank Acquisitions in New Markets, supra note 199.

${ }^{208} I d$.

${ }^{209}$ Id.

${ }^{210} \mathrm{G}$. Fischer, American Banking Structure 386-87 (1968). The FDIC emphasizes availability of options rather than size. "[I]f the FDIC has an institutional bias, it has very little to do with the absolute size of banks but a great deal to do with the number of meaningful competitors available to bank customers in particular states and in local banking markets throughout the country." FDIC Merger Policy-1970-1972, Speech by Frank Wille, Practicing Law Institute Seminars on Bank Acquisitions and Mergers and Other Antitrust Problems, New York City, Oct. 13-14, 1972. See The Battle of Big and Little, TIME, Dec. 18, 1972, at 90.

${ }^{211}$ A Justice Department official, after noting that correspondent banking is particularly important in unit banking and limited branch banking states acknowledged that " $[t]$ he correspondent banking system as a whole is, I am sure, pro-competitive: it helps the local bank offer more sophisticated services and larger loans than such a local bank would be able to do on its own." Antitrust and Correspondent Banking, Speech by Donald I. Baker, American Bankers Ass'n, Annual Convention, San Francisco, Cal., Oct. $19,1971$. 
In its most effective manifestation, correspondent banking enables smaller banks to remain independent and competitive. ${ }^{212}$ Access to the myriad of services provided by the correspondent bank makes it possible for the smaller bank to efficiently and economically respond to community needs while still retaining a personal touch with customers. ${ }^{213}$ Indeed, it is worth noting that one of the justifications (thus far unsupported) for acquiring smaller banks is that the quality of correspondent service has deteriorated, leaving the local area vulnerable to inadequate banking. ${ }^{214}$ Another benefit from the practice is that smaller banks derive the benefit of economies of scale because they are not saddled with the startup costs and other capital commitments necessary to support the services made available by correspondents. ${ }^{215}$ Moreover, to the extent that it effectively provides support services, correspondent banking enhances the small bank's chance of remaining competitive and independent in the face of acquisition-oriented large banks. ${ }^{216}$ In the words of one banker, "the correspondent banking system ... is the keystone upon which the survival of small independent banks rests." 217

The fact that a strong and effective correspondent banking system meshes with antitrust and banking goals furnishes the judiciary with a solid policy basis for resolving close contests over relevant product and geographic markets in favor of plaintiffs so as to permit evaluation of the issues on the merits. For the same

212 It has been said that

without correspondent banking and the growing variety of correspondent services, smaller banks could not survive in the ever more complex business of banking. And thus without correspondent banking it is hard to see how the United States could continue to have its unique banking system under which small banks and giant institutions are able to survive and flourish side-by-side.

Nadler, Three Score Years of Correspondent Banking, B ANkING, July 1968, at 54, 56. See Darcy, Correspondent Aids That Bolster Independent Banking, 55 Burroughs Clearing House, Aug. 1971, at 23; Lawrence \& Lougee, Determinants of Correspondent Banking Relationships, 2 J. Money, Credit \& Banking 358 (1970); Strachen, Holding Company Threat to Correspondent Sjstem, 55 Burroughs Clearing House, Aug. 1971, at 22.

${ }^{213}$ The ultimate beneficiary, or loser, is the consumer: "If the retail bank becomes a captive customer and is prevented from shopping around for a new supplier when dissatisfied, the consuming public must ultimately bear the cost of poorer service and/or higher costs because of the impairment on competition." Darnell, supra note 199, at 314.

${ }_{214}$ Knight, pt. I, supra note 12 , at 6 . On the other hand, proponents of holding companies have sought to allay fears that their activities would mean the demise of smafl banks with the following rationale: "To the contrary, bank holding companies will be required to work diligently to improve the competitive viability of all nonaffiliated banks - weak and strong - within their primary market area, to establish a system similar to, but more effective than, the present system of correspondent banking." Mann, The Reality and Promise of Bank Holding Companies, 90 BANK L.J. 181, 191 (1973).

215 Greenbaum, supra note 39 , at 139 .

${ }^{216}$ It has been said that without correspondent banking, "it would seem doubtful that the high degree of 'local banking' which exists in this country would have remained long beyond 1900." G. FISCHER, supra note 210 , at 121 . 217 CoRrespondent Relations, supra note 18, at 18. 
reason, courts should not hesitate to accept a method of quantifying correspondent banking-interbank deposits-that is generally acknowledged to furnish a reasonably accurate means of measurement. In no case should available measuring techniques be summarily rejected because they are not exactly accurate. Finally, no justification emerges to support the use of any other than established proscriptive standards. Hence the distinction between competitive effects in regional markets and competitive effects in national markets, drawn by the court in First National Bancorporation should be repudiated.

On the other hand, there may arise in some situations the need for enforcement agencies to balance priorities; precluding anticompetitive vertical mergers between city correspondent and country banks could clash with efforts at encouraging "toehold" acquisitions. Brown Shoe justifies antimerger action where a large or medium-sized city correspondent bank acquires a small country bank, market foreclosure exceeds de minimis levels, and there is in motion a trend of vertical acquisitions, resulting in the elimination of city correspondent options for country banks. Such an action may, however, conflict with some possible desirable effects of such a merger. If the city correspondent is, as likely, a large retailer with influence as a potential competitor, entry by toehold (or minor horizontal share) acquisition could have procompetitive consequences in the country bank market. ${ }^{218}$

This dilemma did not exist in First National Bancorporation; if it were ever to arise, it could be resolved by balancing the intensity of the competitive effects on the retail and correspondent lines of commerce. If the country bank market is highly concentrated and is clearly in need of toehold revitalization, then the decision should cut in favor of permitting the merger. Since

218 In First Nat'l Bancorporation the defendant argued that the Government's vertical integration argument as to adverse effects in the country bank market (subsequently dropped) was inconsistent with its toehold theory. But, in fact, Bancorporation's acquisition involved a major banking share of the Greeley market $(31.8 \%)$, not a toehold or minor share.

Both the Federal Reserve Board and Appellees herein pointed out that an argument forbidding an acquisition because other banks in that market would be disinclined thereafter to do business with a competitor and would consequently have fewer offerors of services to choose from would bar any entry into that market by any offeror of correspondent services such as Bancorporation - whether by acquisition (large or small) or by de novo charter. The incongruity of protecting the sensibilities of competitors at the expense of any entry by the big Denver Banks (which Appellant is compelled by the dialectic of its major argument to contend are the only likely entrants) finally penetrated and the argument was abandoned just before trial.

Brief for Appellees at I4, United States v. First Nat'l Bancorporation, Inc., 410 U.S. 577 (1973) (footnotes omitted). 
correspondent banking can produce effects on two market levels, further balancing may be necessary. Desirable effects in retail banking in the country bank market may be outweighed by anticompetitive effects in correspondent banking in the city bank market. This could occur where the acquisition contributes to a trend towards a concentrated market in interbank deposits held by the acquiring city banks.

\section{ConClusion}

This Article develops three general propositions that support the need for an antitrust monitor on the correspondent banking system. First, as a distinct subindustry in the field of banking, correspondent banking involves a substantial and influential commitment of resources in interbank deposits and in service components. ${ }^{219}$ The entry of new participants into the field plus the injection of sophisticated technology into the service package makes likely continued growth in this commitment and in the institutions touched by its impact.

Second, correspondent banking is an important factor in preserving the independence of medium and smaller banks. The practice therefore is critical in implementing and supporting the national antitrust policy which repudiates high market concentration while encouraging some diversity in the size of banks and in customer options. Connection with a city correspondent makes it possible for small independents to respond to competition from affiliates of holding companies or the branches of large banks. Moreover, as technology and the accompanying costs continue to advance, correspondent banking will play an even more important role in supporting the competitive vigor of smaller banks. Given the country bank's dependence upon correspondent services, maintenance of competition among suppliers is mandatory. A congressional report concludes that for these services "to be rendered satisfactorily, it is essential that viable competition exist among banks able to render these services." 220

The third factor is that in the absence of antitrust scrutiny anticompetitive changes could occur which would interfere with the capacity of the correspondent banking system to successfully maintain diversity in size among banks. Vertical integration by merger could dampen competition among city correspondents, 11.

${ }^{219}$ Interbank deposits totaled over $\$ 30$ billion in 1972 . AM. BankER, Dec. 18, 1972, at ${ }^{220}$ Correspondent Relations, supra note 18 , at 13. 
reduce shopping options, and thereby erode the bargaining position of country banks. It could also tend to spread market power from one level of banking to another, either forward into retail consumer markets or backward into raw material markets. Moreover, these conditions would be exacerbated by consequences, such as heightened entry barriers, in the city correspondent's market. Indeed, the prospect of new entrants providing correspondent services could be the most effective force in maintaining a competitive market.

Whether the desirability of antitrust surveillance can be translated into successful results awaits further developments. Certainly further empirical research is needed for satisfactory assessment and resolution of the problems developed here, particularly on the difficult questions of barter pricing and evaluation of the presence and tilt of market power. The First National Bancorporation opinion identified some of the basic legal issues that are likely to pose problems. These issues have not been satisfactorily resolved. Nevertheless, our analysis points to the conclusion that correspondent banking is not so complex as to justify either a reluctance to consider the ultimate issue of competitive effects or the need to resort to variations of standard proscriptive tests. 